\title{
2. Key streams in philosophical inquiry: a selection and succinct overview for the field of public administration - part I
}

\section{INTRODUCTION}

This and the following chapter provide an overview of key streams of philosophical inquiry and delineate key lineages between philosophical ideas and notions and concepts employed in the study and practice of PA. These chapters adopt a mainly chronological way of presenting (Western) philosophical thought, from its roots in ancient Greece to contemporary strands; this ordering criterion may further enable the reader to appreciate the development of topics over time, and the continued dialogue in which philosophers across the ages are engaged around the key issues of being, knowing, behaving, and living together. The repartition of topics between the two chapters is not (entirely) arbitrary, as the philosopher Immanuel Kant is widely considered to have brought about a revolution in philosophical thinking, and one which delineates the contours of 'modern' thinking and its differences from ancient, medieval and early modern thought. It is not by chance that the Kantian notion of the subject - the knowing subject and the moral subject - is the opening point and in certain sense a lynchpin for both the treatment of themes of ontology and PA and issues of epistemology and PA (see Chapters 4 and 6 respectively).

An overview of the topics illustrated in Chapters 2 and 3 is reported in Table 2.1. Importantly, at the end of each major section of this and the following chapter a closing paragraph sums up some of the key implications for PA and relevance for philosophy for PA that can be drawn from the key philosophical themes and notions that have arisen in that epoch; while these succinct closing paragraphs can only hint to elaborations that are then developed in later chapters of this book, they may represent an already useful dashboard - or at least a set of 'pointers' - accompanying the reader as to what can be learnt from philosophical thought which underpins and matters so much for PA. 
Table $2.1 \quad$ A (very schematic) traveller's map through Western philosophy for students of public administration

\begin{tabular}{|c|c|c|c|}
\hline $\begin{array}{l}\text { Epoch/Key } \\
\text { themes - authors - } \\
\text { relevance for PA }\end{array}$ & $\begin{array}{l}\text { Key authors } \\
\text { - philosophies }\end{array}$ & Themes & $\begin{array}{l}\text { Implications for PA/ } \\
\text { relevance for philosophy } \\
\text { for PA }\end{array}$ \\
\hline $\begin{array}{l}\text { Archaic (Greek } \\
\text { Civilisation) } \\
776 \mathrm{BC}-500 \mathrm{BC}\end{array}$ & $\begin{array}{l}\text { Thales, } \\
\text { Anaximander, } \\
\text { Anaximenes, } \\
\text { Heraclitus, } \\
\text { Parmenides (active } \\
\text { around } 500 \mathrm{BC} \text { ) }\end{array}$ & $\begin{array}{l}\text { Introduced the key } \\
\text { philosophical questions, } \\
\text { notably ontological: } \\
\text { the nature of being, the } \\
\text { relationship of being and } \\
\text { thought }\end{array}$ & $\begin{array}{l}\text { No direct relevance - but } \\
\text { key ideas - like that of the } \\
\text { coincidence of being and } \\
\text { thinking - sown here }\end{array}$ \\
\hline $\begin{array}{l}\text { Classical (Greek } \\
\text { Civilisation) } \\
500 \mathrm{BC}-323 \mathrm{BC}\end{array}$ & Plato, Aristotle & $\begin{array}{l}\text { Developed a systematic } \\
\text { and enduring configuration } \\
\text { of the branches of human } \\
\text { knowledge and their } \\
\text { articulation (philosophy as } \\
\text { apex of human knowledge); } \\
\text { Key notions shaping } \\
\text { (Western) thinking, like } \\
\text { 'form/essence', 'causality', } \\
\text { 'potentiality-actuality } \\
\text { distinction' all took shape } \\
\text { here and inform directly } \\
\text { or indirectly all 'scientific' } \\
\text { knowledge }\end{array}$ & $\begin{array}{l}\text { Enduring actuality of key } \\
\text { notions like Aristotle's } \\
\text { four causes (for social } \\
\text { sciences and PA); Political } \\
\text { philosophy established } \\
\text { in this epoch (public } \\
\text { governance) }\end{array}$ \\
\hline $\begin{array}{l}\text { Hellenistic (Greek } \\
\text { Civilisation) - } \\
\text { Roman and Patristic } \\
\text { Philosophy } \\
323 \mathrm{BC}-476 \mathrm{AD}\end{array}$ & $\begin{array}{l}\text { Philosophical } \\
\text { movements } \\
\text { (stoicism, } \\
\text { eclecticism, } \\
\text { scepticism, } \\
\text { Epicure), Greek and } \\
\text { Latin Fathers of the } \\
\text { Church, Augustine }\end{array}$ & $\begin{array}{l}\text { Ethical issues centre stage } \\
\text { in Hellenistic period; Key } \\
\text { concepts brought into } \\
\text { philosophy by the Christian } \\
\text { Revelation: notion of } \\
\text { universal salvation and } \\
\text { the foundation of rights of } \\
\text { each human being - beyond } \\
\text { ethnicity, status, or else - as } \\
\text { God's sons; Notion of } \\
\text { creation of universe out of } \\
\text { nothingness; Notions of } \\
\text { eternity and time revisited in } \\
\text { light of creation; Trinitarian } \\
\text { conception of God and } \\
\text { notions of 'person'; Free } \\
\text { will, original sin and } \\
\text { individual responsibility }\end{array}$ & $\begin{array}{l}\text { Pursuit of virtues (stoicism); } \\
\text { Notion of Charitas as } \\
\text { gratuitous and absolute love, } \\
\text { underpinning notions of } \\
\text { benevolence and the caring } \\
\text { for each human being, and } \\
\text { intellectual roots of modern } \\
\text { age 'universal' human rights } \\
\text { and contemporary notions of } \\
\text { human person and welfare } \\
\text { state/social rights }\end{array}$ \\
\hline
\end{tabular}




\begin{tabular}{|c|c|c|c|}
\hline $\begin{array}{l}\text { Epoch/Key } \\
\text { themes - authors - } \\
\text { relevance for PA }\end{array}$ & $\begin{array}{l}\text { Key authors } \\
\text { - philosophies }\end{array}$ & Themes & $\begin{array}{l}\text { Implications for PA/ } \\
\text { relevance for philosophy } \\
\text { for PA }\end{array}$ \\
\hline $\begin{array}{l}\text { Medieval Age } \\
476 \mathrm{AD}-1492 \mathrm{AD}\end{array}$ & $\begin{array}{l}\text { Anselm, Thomas } \\
\text { Aquinas, Scotus, } \\
\text { Ockham }\end{array}$ & $\begin{array}{l}\text { The nature of universal } \\
\text { concepts; The ontological } \\
\text { proof of the existence } \\
\text { of God; Scholastics and } \\
\text { the essence-existence } \\
\text { distinction as lynchpin } \\
\text { (being as gifted, creatures as } \\
\text { partaking of Being) }\end{array}$ & $\begin{array}{l}\text { Understandings of universal } \\
\text { concepts underpin different } \\
\text { contemporary perspectives } \\
\text { on conceptions of PA; } \\
\text { Potentiality-actuality } \\
\text { distinction a central issue in } \\
\text { social sciences and PA }\end{array}$ \\
\hline $\begin{array}{l}\text { Renaissance } \\
\text { mid-14th to mid-16th } \\
\text { century } \mathrm{AD}\end{array}$ & $\begin{array}{l}\text { Erasmus, Leonardo, } \\
\text { More, Machiavelli }\end{array}$ & $\begin{array}{l}\text { Humanism: human being as } \\
\text { micro-cosmos; Universality } \\
\text { and immutability of human } \\
\text { nature in each individual; } \\
\text { The pursuit of perfection } \\
\text { through virtues; Prominence } \\
\text { of artistic expression in } \\
\text { pursuit of truth }\end{array}$ & $\begin{array}{l}\text { Roots of virtue discourse } \\
\text { in Public Governance; } \\
\text { Contribution of } \\
\text { (Administrative) History to } \\
\text { knowledge generation in PA; } \\
\text { Coinage of notion of Utopia; } \\
\text { Significance and usage of } \\
\text { artistic expressions in PA } \\
\text { inquiry (e.g. Lorenzetti's } \\
\text { 'The Good Government') }\end{array}$ \\
\hline $\begin{array}{l}\text { Early Modern Age } \\
\text { 16th to } 18 \text { th century } \\
\mathrm{AD}\end{array}$ & $\begin{array}{l}\text { Descartes, } \\
\text { Leibniz, Spinoza, } \\
\text { Locke, Hobbes, } \\
\text { Berkeley, Hume, J. } \\
\text { Stuart-Mill }\end{array}$ & $\begin{array}{l}\text { Rationalism 'vs' empiricism; } \\
\text { Subject as starting point } \\
\text { of philosophising and the } \\
\text { new metaphysical systems; } \\
\text { Dualism mind-matter and its } \\
\text { conundrums; The scientific } \\
\text { revolution and physics as } \\
\text { the pattern of scientific } \\
\text { knowledge }\end{array}$ & $\begin{array}{l}\text { Empiricism and the origin } \\
\text { of concepts in the mind; } \\
\text { Rationalism and the role of } \\
\text { innate ideas in PA research; } \\
\text { The role of the subject in PA } \\
\text { research and practice }\end{array}$ \\
\hline $\begin{array}{l}\text { Enlightenment (18th } \\
\text { century) }\end{array}$ & Voltaire, Wolff & $\begin{array}{l}\text { Critical reason as source } \\
\text { of human liberation } \\
\text { ('Enlightenment'); The age } \\
\text { of the revolutions - English } \\
\text { revolution (17th century), } \\
\text { American and French } \\
\text { revolutions; Industrial and } \\
\text { demographic revolutions } \\
\text { - and the principles of } \\
\text { universal human rights; } \\
\text { Sovereignty to the people; } \\
\text { Self-determination of } \\
\text { peoples/the modern Nation } \\
\text { State }\end{array}$ & $\begin{array}{l}\text { Universalistic human } \\
\text { rights; Conceptions of } \\
\text { liberal-democracy and the } \\
\text { form of the modern Nation } \\
\text { State; Initial overcoming of } \\
\text { patrimonial state and roots } \\
\text { of modern administrative } \\
\text { state }\end{array}$ \\
\hline
\end{tabular}




\begin{tabular}{|c|c|c|c|}
\hline $\begin{array}{l}\text { Epoch/Key } \\
\text { themes - authors - } \\
\text { relevance for PA }\end{array}$ & $\begin{array}{l}\text { Key authors } \\
\text { - philosophies }\end{array}$ & Themes & $\begin{array}{l}\text { Implications for PA/ } \\
\text { relevance for philosophy } \\
\text { for PA }\end{array}$ \\
\hline $\begin{array}{l}\text { Modern philosophy } \\
\text { (19th and 20th } \\
\text { century) }\end{array}$ & $\begin{array}{l}\text { Kant, Fichte, } \\
\text { Schelling, } \\
\text { Hegel, Marx, } \\
\text { Schopenhauer, } \\
\text { Nietzsche, Comte, } \\
\text { Rickert, Carnap, } \\
\text { Mach, Avenarius, } \\
\text { Poincaré, Dilthey, } \\
\text { Windelband }\end{array}$ & $\begin{array}{l}\text { Kant, the revolution } \\
\text { of the subject, and the } \\
\text { foundation of morality and } \\
\text { the limits of the knowable; } \\
\text { Historicism; Idealism; } \\
\text { Marxism; Positivism; } \\
\text { Conventionalism; The } \\
\text { sciences of the spirit }\end{array}$ & $\begin{array}{l}\text { Kant and the foundations } \\
\text { of public governance in } \\
\text { the knowing and moral } \\
\text { subject; Historicism } \\
\text { and the transformative } \\
\text { dynamics of administrative } \\
\text { systems; Contemporary } \\
\text { epistemologies in PA } \\
\text { and their roots in modern } \\
\text { philosophies; Marxism, } \\
\text { Gramsci and the notion of } \\
\text { power in PA; The sciences } \\
\text { of the spirit and the nature } \\
\text { of PA as interdisciplinary } \\
\text { social science, art, } \\
\text { profession and humanism }\end{array}$ \\
\hline $\begin{array}{l}\text { Contemporary } \\
\text { strands }\end{array}$ & $\begin{array}{l}\text { Husserl, Heidegger, } \\
\text { Jaspers, Sartre, } \\
\text { Lévi-Strauss, } \\
\text { James, Russell, } \\
\text { Wittgenstein, } \\
\text { Whitehead, } \\
\text { Gadamer, } \\
\text { Habermas, } \\
\text { Mounier, Maritain, } \\
\text { Bergson }\end{array}$ & $\begin{array}{l}\text { Phenomenology; } \\
\text { Existentialism; } \\
\text { Structuralism; Anglophone } \\
\text { streams: pragmatism, } \\
\text { analytical philosophy, } \\
\text { and process philosophy; } \\
\text { Hermeneutics; Personalism, } \\
\text { spiritualism, and } \\
\text { neo-scholastics }\end{array}$ & $\begin{array}{l}\text { Philosophical roots } \\
\text { of conceptions and } \\
\text { interpretations of PA: } \\
\text { the knowability of the } \\
\text { essences in PA inquiries; } \\
\text { The existentialist } \\
\text { public administrator; } \\
\text { Social structures, social } \\
\text { ontology and PA; Process } \\
\text { philosophy and process } \\
\text { approaches to PA studies; } \\
\text { Conceptions of time and } \\
\text { PA study and practice; } \\
\text { Spiritualism, personalism } \\
\text { and the promotion of human } \\
\text { well-being as guiding } \\
\text { principle in normative } \\
\text { conceptions of PA }\end{array}$ \\
\hline
\end{tabular}

\section{ORIGIN OF PHILOSOPHY AND THE PRE-SOCRATICS}

For the great Greek philosopher Aristotle, philosophical investigation is above all inquiry into the causes of things. Aristotle, who is also considered the first historian of philosophy, classified his predecessor philosophers according to the kind of cause their philosophy probed into. Aristotle himself worked out 
a system of four types of causes: material, formal, efficient and final cause (we delve into this important notion later and also in Chapter 4). In this book we adopt a much more 'textbook' classification, mixing a mainly chronological criterion with a thematic criterion. We first illustrate ancient (Greek) philosophy, then turn to early Christian and medieval philosophy, to early modern philosophy, and finally delve at greater length into modern and contemporary philosophy. We will only succinctly and selectively highlight certain main philosophical streams, according to an ordering process also partly guided by our own necessarily subjective attribution of significance of strands of philosophical thought for PA studies. We dwell in key passages to illustrate in more detail concepts and notions that are then employed in the subsequent chapters for addressing PA themes and debates (one such notion is that of the four causes, which has seen a recent revival in the field of PA (Pollitt, 2012) and in a broader range of social sciences, for example in international relations (see Kurki, 2008, as an underpinning of 'critical realist' accounts).

Before we begin, it may be worth recalling the cultural, religious as well as socio-economic and political conditions in ancient Greece that constituted the fertile ground that paved the way for the birth of philosophy (Reale and Antiseri, 1988, pp. 5-10). Ancient Greek civilisation encompassed the territory of contemporary Greece, southern Italy and the Western coast of the Anatolian peninsula, with the city of Miletus, in nowadays Western Turkey, representing a key centre for the initial development of philosophy. The emergence of philosophical speculation towards the end of the so-called archaic period (800-500 BC) was preceded by the consolidation of a formidable literature in the Greek language, ${ }^{1}$ which reached its apex in the poems attributed to the poet Homer, namely the Iliad and the Odyssey. It has been noticed how a key feature of Homeric poetry is the 'art of motivation', the continuous search, weaved into the poetic text, for the causes of the events that are narrated, the reasons why events occurred. Even if causes may here take a mythical form, the quest for the cause of things permeates the great Greek literature in a way that may have paved the way for the subsequent philosophical speculation. Another key trait of Homeric epic is its thrust towards presenting reality in its entirety: the world of the gods and the human world are equally represented in these poems, as are the just and the unjust in human life, the good and the bad, the joyful and the painful. The speculation on reality in its entirety, and on the position of the human being within it, is already prefigured in the great Greek literature, before taking centre stage in the full-blown philosophical speculation of the Classical period (500-323 BC) and the Hellenistic period (323-30 BC). Also Greek public religiosity displayed remarkably peculiar traits: Greek gods resembled human or natural qualities amplified and brought to perfection, rather than distant deities. It was, in many respects, a naturalistic religion that

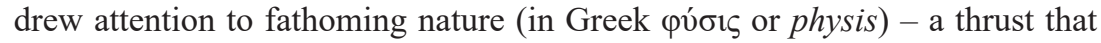


characterised the Greek philosophical enterprise. Finally, during the centuries that immediately preceded the birth of philosophy, the Greek society changed significantly: it became wealthier and its economic strength freed time, at least for part of the population, from the constraints of material needs to devote to study and reflection. More importantly, however, Greek city states developed a climate of political liberties, identification of the 'citizen' (itself a Greek invention) with the political community, and free speech, which provided the breeding ground for free critical thinking that was conducive to philosophical speculation.

It was philosophers collectively known as the Milesians (because they were all from the city of Miletus) who initiated the investigation on 'Being' in itself - the study of being and becoming, of reality and existence - which is referred to with the term 'ontology': the study $(\lambda \circ \gamma 1 \alpha$, logia) of being (the genitive of

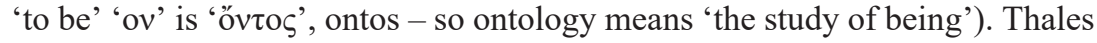
(c.625-545 BC) is generally attributed as the founder of philosophy because he devoted his speculation to the search for the origin or foundation of all things, their ultimate nature. He claimed to have found it in water, but this should not be intended as physical water, but rather the water is an attempt to identify and

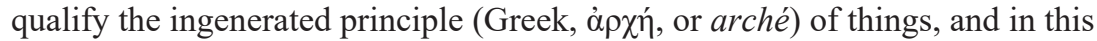
sense the claim that water is the origin of things is not a theory of the physical universe, rather a metaphysical conception to refer to the totality of being.

Anaximander, a pupil of Thales, moved the search further by introducing the notion of 'what does not have limits', the infinite or unlimited (Greek ö $\pi \varepsilon 1 \rho \circ$, or apeiron) as the principle of things. This principle embraces, surrounds and underpins all that is, exactly because each limitation (a word which in its Latin origin means 'border') can only stem from the unlimited (borderless). The search for the principle of all things moved further, beyond the rather more simplistic notion of 'water' (albeit metaphysically interpreted, as we tried to illustrate) and towards the purely intelligible notion of the infinite. Anaximander also addressed questions that Thales didn't - notably why and how all things derive from the principle, developing an answer inspired by orphic myths (a religiosity of Eastern derivation that was widely practised privately in ancient Greece) about injustice and atonement being the sources of the dynamics of the world we live in, and how this world derives from the principle. Anaximenes, a generation younger than Anaximander, follows in the trail and revisits the thought of his masters. Although his reference to air, rather than water, as the origin of things might be considered a step back from Anaximander's conceptualisation of the infinite, it represents a more 'rational' attempt to tackle another crucial question: explaining, by resorting to the very nature of the principle of everything (ontological foundation), how becoming occurs, how movement and change are introduced into the world. We will find some of these ideas in the thought of Heraclitus, the philosopher of becoming 
and a lingering source of inspiration of all 'processual' philosophies, of all the ontologies of becoming, from the ancient times to Hegel and Whitehead.

The fragments of the works by Heraclitus (probably part of a book on nature) that have crossed the ages until our epoch suggest that this philosopher brought to a new height the intuition of the Milesians about universal dynamism. If those philosophers thought of dynamism as deriving from the principle of all things, Heraclitus appears to have put movement and change itself as the principle. In sentences that have become immortal, he stated that everything is in motion and nothing stays still, that if we step into the same river twice, we cannot put our feet into the same water, since the water is not the same two moments together' (Kirk et al., 1983, fragment 214); the second moment we descend into the river, the water and we, ourselves, have changed. This seems to entail an ontology of becoming: that each and every moment, for any reality - without exception - to be something means not to be any more what that reality was a moment before. This poses the crucial problem of how can it happen that being derives from non-being, and non-being from being: that something that exists comes out of nothingness, and that something that exists goes into nothingness. This problem has puzzled philosophers over the centuries - and still does.

Heraclitus's philosophy is often read in stark contrast with Parmenides's. Parmenides belonged to the school of the Eleatics, whose founder is traditionally identified in Xenophanes, active in the Western Greek colonies, located in nowadays Southern Italy. In sentences as equally immortal as Heraclitus's, Parmenides claimed that (we report and adapt the translation provided by Kenny, 2010, p. 161): 'what you can call and think must Being be - for Being can, and nothing cannot, be [and] Never shall this prevail, that Non-Being is ... Non-Being you won't grasp - it can't be done - nor utter; being thought and being are one'. These sentences have sparked a debate that has lingered for over two-and-a-half millennia. It has been argued whether 'Being' means 'that to which a predicate can be attached' and Non-Being 'that to which no predicate can be attached', or whether the claims refer to a radical ontology of Being as the totally positive, and Non-Being the totally negative, and hence that no change or movement is possible because Being is, immutable since the beginning and forever, and cannot trespass into Non-Being, and Non-Being 'is not' and never shall trespass into Being. ${ }^{2}$

Parmenides and Heraclitus are claimed to have set the terms of the dispute over whether the ultimate nature of all things and the totality of reality lies in 'being' or in 'becoming' (at times this opposition is narrowed down to the categories of 'static' versus 'dynamic' ontologies, and derived analytic apparatuses - but this dichotomy might be quite reductionist), a dispute that has featured centre stage in the philosophical debates since. 
Before turning to the giants of classical metaphysics - Plato and Aristotle - we mention Pythagoras and the school of the Pythagoreans. As well as contributing powerfully to the development of mathematics, from a philosophical standpoint they were the first to point out that reality may be read and understood through 'numbers', that the principles of the numbers are (so they purport) the principles that govern all things. Nowadays we are accustomed to thinking that nature is investigated by searching for mathematical, functional relations (maths is the language of modern physics and the natural sciences), or that sounds and music can be expressed in mathematical forms. This has become so obvious to us that is has led our epoch to become oblivious of how amazing these discoveries are: going back to the writings of these scholars may help resuscitate the amazement that stemmed from this discovery. Two fundamental qualifications are in order: first, after Aristotle we are accustomed to conceiving numbers as mental abstractions, as an entity of reason. Pythagoreans rather conceived of numbers as 'real' entities, and hence the principles of numbers (the principles and laws of maths) are by Pythagoreans conceived of as principles 'really' underlying all things. This ushers us into the issue of the distinction between entities of reason and 'real' embodied entities - a distinction that is centre stage throughout philosophical speculation from Aristotle's 'metaphysics of the form' to the 'dispute over the nature of the universals' (topics to which we return). Second, it may be stated that with the Pythagoreans humankind made a giant leap in that it has learnt to read reality through reason, albeit a specific expression of reason that is mathematical reason. After the contribution made by this philosophical school, the world is no longer seen as dominated by arcane and indecipherable powers, but rather it is seen as expressed in numbers: order, rationality, detectable verity become centre stage. Over the course of the development of philosophical thought, there have been gloomier visions about the penetrability of reality through reason, which are at odds with this Pythagorean vision - but philosophising as 'the science of reason' undoubtedly made a major leap thanks to the contribution of this school.

Finally, it should be noted that for reasons of brevity we are unable to introduce other giants of Greek philosophy, such as Leucippus, Democritus and the Atomists, Empedocles, and Anaxagoras, but it is important to emphasise what inexhaustible sources these philosophies represent for the contemporary thought. One may notice, for example, striking parallels between Anaxagoras's philosophy of the 'seminal reasons' as explanations of becoming and contemporary strands of Whiteheadian 'process philosophy'. Later in the book (Chapter 4) we will discuss similarities and dissimilarities between some contemporary trends in PA and the philosophical thought of the Sophists (the word being in capital to distinguish it from nowadays usage of the term), namely Protagoras, the doyen of the Sophists, and his many acolytes 
who formed a highly influential school of thought active in ancient Greece. Sophists were the target of the darts of Socrates and his pupil Plato, and it is to his thought we now turn.

Implications for PA/Relevance for Philosophy for PA: while most of the ideas and notions introduced in this section may not have a direct application to the field of PA, it would be impossible to underestimate the significance of these developments for virtually every form of knowledge, thereby including knowledge generated in the field of PA. Moreover, one thread of this initial section has been to highlight how contemporary discourses in philosophy and the social sciences have been anticipated and how they have found their seeds in ancient Greek philosophical debate: we have just noticed in the previous paragraph the parallels between Anaxagoras's notion of seminal reasons as explanations of becoming and key tenets of process philosophy; we have also highlighted the impressive resemblance between the controversy between the Sophists, on one side, and Socrates (and Plato and Aristotle), on the other side, and the contemporary contests between relativists-post-modernists and the (critical) realists, not just in PA but across the social sciences.

\section{CLASSICAL METAPHYSICS}

We now discuss how 'classical' metaphysics was developed in the hands of the two giants of philosophy, Plato and Aristotle. For thematic (rather than chronological) coherence, we will discuss the thought of Plato to Plotinus, on one hand, and Aristotle's metaphysics, briefly sketching his huge inheritance, on the other hand.

There is a saying that 'Plato asked all the questions (of significance to philosophy), and his mentee Aristotle provided most of the answers we can reasonably aspire to achieve; the others added glosses'. This is obviously an exaggeration, but the significance of the contribution of these two masters of thought for the development of philosophy can hardly be exaggerated.

Aristocles, better known as Plato (428/427-347 BC), expressed himself through the rhetoric form of dialogues in which different philosophical stances are debated by fictional characters (an English translation of all his works can be found in Plato, 1997). Although Plato himself was not a protagonist in the dialogues, Socrates - who had been his mentor -systematically is, and it is generally pointed to what the character Socrates says for gleaning what might have been Plato's 'viewpoint' on the philosophical issue debated. It appears Plato attached great significance to the dialogic form, which was not just a means of expression, but in a sense was for him the essence of philosophising. As well as the more public lectures that were reported in the dialogues, he held conversations in small groups with acolytes at the school he established in Athens, significantly called 'Academy', in which he is said to have provided 
more in-depth understanding of what was publicly reported in the dialogues. The dialogue form has proven inspirational, yet not uncontroversial, and exegetes and interpreters have struggled over the subsequent two-and-a-half millennia to interpret his thought. We can only leave to the experts to delve into these crucial issues of interpretation, here furnishing but a brief introduction to some key traits of his philosophy.

Plato used the metaphor of the 'second navigation' to suggest that reality is in a sense two-tiered: there is the world of phenomena and a world beyond phenomena, meta-phenomenal or, with a term that gained currency later and has become conventional, metaphysical (literally meaning 'beyond the physical world'). We have already pointed out how in the pre-Socratics the search for the 'ultimate nature', for 'the totality of being' beyond the variety of the elements gained traction and represented a quantum leap from previous approaches to human understanding of the world, and yet it is only with Plato that a distinction is introduced between the material and the immaterial, between the world that can be perceived through the senses and the world of what is intelligible: the world of ideas. It is only with Plato that nature and the cosmos come to be considered no longer as the totality of being, but as only a part of it, the totality of the things that appear to the senses as opposed to the ultimate totality, whose most important part is made of what is intelligible. Things in this world participate of ideas, of which they are a mere resemblance (it may be noticed this conception of 'participation of one reality to another, higher-level reality' introduces the philosophical notion of 'analogy').

What are these ideas? Tonnes of inks have been poured on the topic and we can here only scour the surface of the debate. We take as a starting point the commentary by Kenny to the seventh of the letters traditionally attributed to Plato (Kenny, 2010, p. 44, last sentence postponed), where Plato illustrates his doctrine with the example of a circle:

There is something called a circle; it has a name, which we have just this minute used. Then there is a definition, a compound of nouns and verbs. We might give 'The figure whose limit is at every point equidistant from its centre' ... Third, there is what we draw, or rub out, or rotate, or cancel. The circle itself which all these symbolize does not undergo any such change and is a quite different thing. In the fourth place we have knowledge, understanding and true opinion on these matters these collectively are in our minds and not in sounds or bodily shapes, and thus are clearly distinct from the circle itself and from the three entities already mentioned ... and there is a fifth thing which we have to postulate, which is that which is knowable and truly real.

This fifth thing is the idea of a circle: what Plato refers to as idea in itself and by itself. The idea is an objective reality that is not the property of any individual mind (this is pointed out by Plato where he highlights the difference 
between the knowledge of a thing and the idea of the thing in itself: the circle pre-exists the subject getting to know it).

It may be worth noticing what is left out: in this conception there is no reference to empirics and the empirical (Kenny, 2010). This point is picked up by Aristotle for whom knowledge starts from the senses, albeit it is only the intellect that makes it possible. In this regard, the two contrasting positions between the two philosophers were made immortal in the painting The School of Athens by the Italian painter Raffaello, in which Plato points his forefingers towards the sky - the world of ideas - and Aristotle towards the earth: the sensible world. This picture forms the cover of this book.

The synthesis to which Plato came with the notion of the world of the ideas encompasses what - in different ways - Heraclitus and Parmenides had already introduced, albeit in very different philosophical systems: that being and logos (the Greek word for 'word' but also 'reason') are interpenetrated, that the horizon of thought is the horizon of being, that thought and being are the same; that Being is (Parmenides) and becomes (Heraclitus) within the horizon of thought. What Heraclitus referred to as the intelligence of things', the logos which governs all things in their incessant becoming, is what Parmenides referred to when he stated that 'the same is being and thinking, the same is thinking and what thinking is in function of, because without being, in which it is expressed, you will not find thinking: in fact [thinking] is or will be nothing outside of being' (Parmenides, Fragments, B8).

Plato also ordered the ideas in a hierarchy, famously placing at the summit the idea of the 'good in itself'. There is a sense in which this is also an extraordinary innovation from his predecessor Parmenides: by positing an order among ideas, it ensues the logical implication that an idea is not another idea. This statement enables getting out of the paradox (if we may call it this way) of the impossibility of change that was purported by Parmenides: 'Being is, and Non-Being is not', that is, in an absolute sense Being can never transition into Non-Being, but it exists a non-being (in lower-case letter) intended as diversity and alterity, for example a square is not a circle. Every idea, in order to be that idea necessarily has to be diverse from all other ideas. This concept of a sort of 'relative' (as opposed to absolute) non-being will be picked up more systematically by Aristotle for combining the explanation of movement and becoming with the eternity of being.

Finally, Plato has developed a widely elaborated political-philosophical thought, notably in The Republic. His conception of the justice and the common good is crucial. This is discussed in Chapter 5, where the conception of common good is the starting point for a tour on the issue of justification of a(ny) political system, and its enduring and far-reaching implications for the field of PA. 
Plato has left a huge inheritance. His teachings have fallen on fertile ground, notably his influence directly exerted on his pupil Aristotle. His written works, an important part of which have been conserved and transmitted for posterity, have elicited philosophical speculations across the millennia. Many philosophical strands stemmed from his work, of which 'neo-Platonism' (evoked in different guises over the centuries and indeed more often to be referred to Plotinus's thought) is but one of them. It may be argued that an entire 'fundamental orientation' in philosophising, a basic stance or line of thought of special significance (also for its continued influences on contemporary social sciences and public affairs) stems from Plato's thought: all philosophies that posit interiority (that is, reason, innate ideas, (self-)conscience) as the starting point of philosophising, rather than sensorial perception, may be claimed to have Plato as their ascendant. Philosophies that take as their commencement interiority constitute a stream that was developed - amongst innumerable others - by philosophers such as Plotinus, Augustine, and on through the ages to Descartes, one of the founders of modern philosophy, to contemporary philosophers like Bergson. Descartes's famous 'cogito, ergo sum' (I think, then I am) posits as the only certainty the doubting of everything by the subject. The more complete form of Descartes's famous statement is 'I think, doubting being an act of thinking, then I am', which therefore takes interiority as the starting point of philosophising. As discussed widely in Chapter 4, a range of approaches not just in philosophy but also in the applied social sciences and specifically in PA have their roots in rationalism, spiritualism and the notion that ideas are, at least partly, innate. The roots of these philosophical stances can in many important respects be ascribed to the philosophy of Plato.

We can now turn to the other giant of metaphysics: Aristotle from Stagira (384/383-322 BC), a pupil of Plato at his Academy for over a quarter of a century 'and it can safely be said that in no other occasion in history was such intellectual power concentrated in one institution' (Kenny, 2010, p. 57), although after the death of Plato Aristotle left the Academy and Athens, to then return only later on and establish his own school, known as Lyceum, or the Peripatetic school.

For Aristotle ${ }^{3}$ (see Figure 2.1), knowledge requires both intellect and experience: one divorced from the other is insufficient to attain the knowledge of things. Hence, differently from Plato, the senses (apparently banal as it may seem, he was the first to point out human beings have exactly five senses sight, hearing, touch, smell, taste - and none has been added to the list or subtracted since) are part and parcel of the process of knowing. According to Aristotle, philosophy is the inquiry into the causes of things, and metaphysics is primarily the search of the prime causes, the causes of everything. He identifies four causes: material, formal, efficient and final. The material cause is the material element of which a thing is made. To borrow Kenny's 


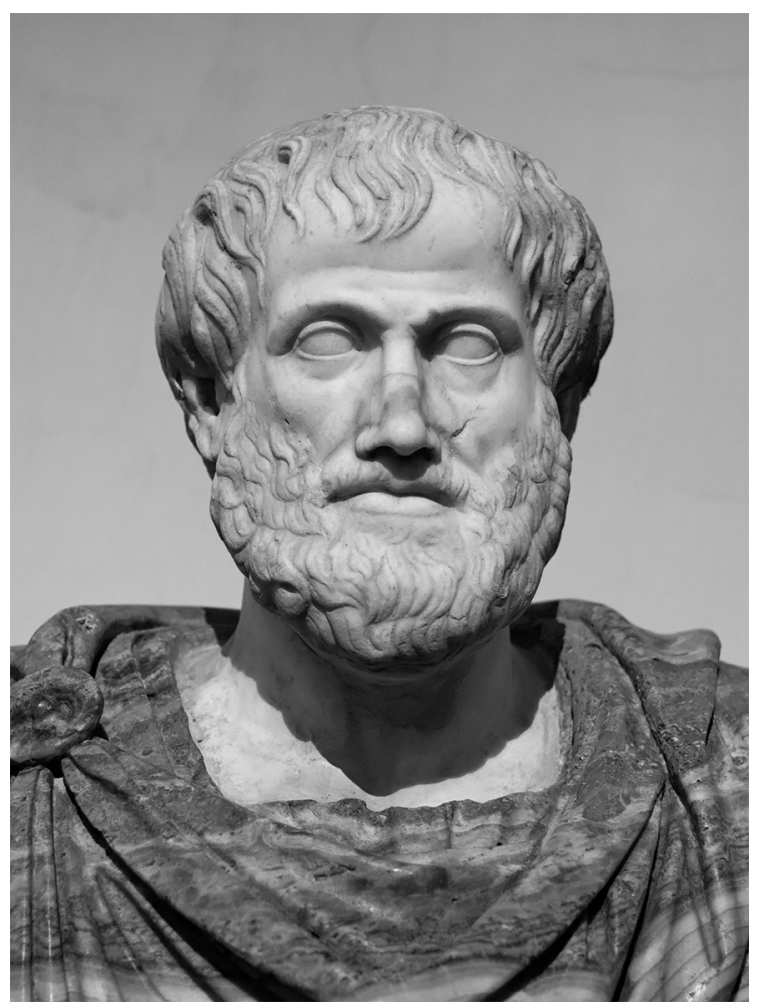

Source: https://en.wikipedia.org/wiki/Aristotle (accessed in 2017 and 7 April 2020).

\section{Figure 2.1 Aristotle}

metaphor of a chef cooking a risotto $(2010$, p. 8$)$, the material causes of the risotto are the ingredients of which it is made; in the case of a human being, the material causes are the flesh and bones of which she or he is made. The formal cause is the form or essence of a thing. For Aristotle, form is unity and organisation of elements, the 'what it is' of something (the Greek term is eidos, form - what gives something the form that makes it to be what it is; the common Latin translation is quod quid est or quidditas, what something is). This notion is central to Aristotle's philosophy and to all metaphysics and we will discuss it further later. Continuing for the moment with the risotto example, the recipe for the risotto is its formal cause, the 'order' that makes ingredients to form a risotto. Material and formal causes are in a sense intrinsic and static: they describe what something is, not why it comes to being (or to corrupting and dissolving). The 'extrinsic' or 'active' causes are the efficient 
and the final ones. The efficient causes are the forces for change, what makes change happen. In the risotto metaphor, the efficient cause is the chef acting on the ingredients according to the pattern set by the recipe: the cooking is the efficient cause. The final causes are the goals or ends (in Greek, telos), why something is brought about: the satisfaction of the clients of the restaurant who order a risotto is the final cause. The system of the four causes as worked out by Aristotle is of enduring significance. In Chapter 6 we provide a systematic examination of the contemporary significance of Aristotle's four causes for PA (and the social sciences).

Besides the system of the four causes, Aristotle (see The Complete Works, English edition 1984) developed a range of concepts that have since formed the backbone of metaphysics. ${ }^{4}$ We have already encountered the notion of form as principle of unity and organisation of elements: what makes a person to be a person, a horse to be a horse, or a triangle to be a triangle. Aristotle strove with the issue of what distinguishes a specific individual from an idea (intended as the form or essence that all individuals having the same nature share - for example, that of being a human being, or a horse). In this perspective, individuals are the synthesis of matter and form, and in this process matter acts as the principle of individuation: two human beings share the same form (they are 'human beings', it is their essence) and are made distinct (individuated) by matter: the matter composing me as the author of this book is not the same matter composing you, reader of this book - we share the form of human beings, we are distinguished by the matter. A related notion is that of 'entelechy', the becoming actual of what is only potential: this happens only when form is given to matter (though the two - form and matter - can never be distinguished in practice, but only conceptually). Although, as we shall see, the notion of matter is not less problematic than that of idea, all philosophies and all approaches to the study of social realities that share a thrust towards gaining an understanding of the essence of the things that are being studied have, to a smaller or bigger extent, their roots in Aristotelian philosophy.

Other key notions were developed by the philosopher of Stagira and bequeathed to philosophical speculation for the subsequent two-and-a-half millennia. First, the notion of the categories of being: the first (foremost) category is that of substance; the other categories are: quality; quantity; relation; action or acting; receiving or undergoing an action; place; and time. By means of these categories, Aristotle introduces 'diversity', and hence the possibility of a relative non-being, tackling the issue raised by Parmenides in the same way Plato did: a thing 'is' (nothing can be predicated of the absolute 'non-being'), but it may 'not be' in one place, or not be at a given moment in time. In this sense, therefore, non-being occurs in a relative, rather than an absolute sense. Second, the distinction between potentiality and actuality: an embryo in a woman's womb is 'in potentiality' an adult human being, though not in actu- 
ality. Potentiality and actuality apply to all categories. In order to explain how things transit from non-being to being, from potentiality to actuality, Aristotle in his metaphysical system posited God as the pure actuality, which enables all things to come into being. Third, the distinction between haphazard and substance: haphazard for Aristotle is a way of being that depends on another being and is not related to the nature of the thing (its essence or form, or substance): a human being may be seated or standing, may be tanned or pale, and so on, without this altering the substance or essence of what 'being a human being' is. Fourth, the notion of correspondence of being as truth, whereby it is the correspondence between what the human mind links, on one hand, and the fact that these things are actually linked in reality, on the other hand, that determines the 'truth value' of a proposition: what was later summarised in the scholastic philosophy (developed in the Middle Ages drawing from Aristotle) as adaequatio intellectus nostri ad rem: the adequacy or correspondence between our intellect and the thing. For Aristotle, this notion does not concern being in itself, rather it pertains to the field of the logic, intended as the criteria the mind has to apply for knowing what is real.

Indeed, Aristotle is considered the founder of logic, and he elaborated a method of logical reasoning, the syllogism, which for centuries has been synonym of the logic. In its very basic structure, a syllogism is based on a major and a minor premise. The major is an assertion of general validity (e.g. all human beings are mortal); the minor premise is a statement (like a qualification) on a specific case (e.g. Plato is a human being). The structure of the syllogism enables arriving at a demonstration or conclusion (Plato is mortal). Aristotle also laid the foundations for what later came to be referred to as 'practical syllogism', a way of relating means and ends. Aristotle describes in his Nicomachean Ethics (III book, Chapter 3, 2002 for an English edition) the relationship between ends and means in the following way:

We deliberate not about ends but about means. For a doctor does not deliberate whether he shall heal, nor an orator whether he shall persuade, nor a statesman whether he shall produce law and order, nor does anyone else deliberate about his end. They assume the end and consider how and by what means it is to be attained; and if it seems to be produced by several means they consider by which it is most easily and best produced, while if it is achieved by one only they consider how it will be achieved by this and by what means this will be achieved, till they come to the first cause, which in the order of discovery is last.

Recently, practical syllogism has continued to draw the attention of philosophers, for example von Wright (1971), and its theoretical potential for framing PA as a form of practical reasoning has been explored recently by Virtanen (2018). 
Aristotle also made a major contribution to ethics, and elaborated a conception of 'virtue' that has travelled the ages. Virtues for Aristotle are acquired. They are a state of character that is expressed both in purpose and in action (it is praxis, the Greek word for the purposeful action, the action shaped by values and sense of direction; Kenny, 2010, p. 213). He distinguished between two types of virtues: virtues as the 'proper mean', that is, avoiding either excess or defect, striking the proper balance between opposing impulses or passions which by their nature tend to the excess (so, for example, the temperate person will avoid drinking or eating too much, but also too little); and virtues as the attainment of perfection according to one's proper nature. The proper nature of the human being as a 'rational animal' lies in the full deployment of reason. Reason can be distinguished into a practical reason and a contemplative reason. Practical reason is concerned with the knowledge of the mutable circumstances of life and, in this case, a fully rational life will be one lived in wisdom, that is, fully guided by the practical reason (although the philosopher of Stagira did not provide a systematic account of the structure of practical reasoning, the previous excerpt briefly hints at Aristotle's reflections on practical syllogism). Contemplative reason is orientated towards the understanding of the immutable and eternal truths, which is the goal of philosophy; contemplative reason leads to a fully realised life, to the fulfilment of our nature as human beings: a notion expressed by the Greek word Eudaimonia, the living of a full life. This notion is central to Aristotle's and Plato's political-philosophical notion of the common good, which we specifically discuss in Chapter 5. The notion of virtue would permeate medieval thought and up to the modern and contemporary age - albeit challenged. We will ponder over its continued significance for public governance and public administration in Chapter 6 by revisiting the work The Good Government by the great artist Ambrogio Lorenzetti.

Finally, Aristotle also worked out a famous taxonomy of the forms of government, which he based upon a wide survey of the constitutions of Greek city states, a work that credited him as the founder of comparative politics (and comparative PA, Aristotle, 1962). He distinguished between three virtuous forms of government - kingship, aristocracy and politeia - and three corrupt forms - tyranny, oligarchy and democracy (the last one would in later epoch take on a more positive connotation than in Aristotle's conception), and delves in insightful ways into the relative strengths and weaknesses of each of them, and their long-term sustainability. Aristotle distinguished between the qualities of an individual and the qualities as a member of a political community, that is, a 'citizen'. Aristotle's speculation about the virtues of the citizens and the governors that enable the attainment of the well-being of all members of a given political community have set the bases for centuries of philosophical and civic thought about 'virtue politics' and the role of virtues in public governance and the significance of civic participation to the destinies of one's own political 
community, and notably its self-sufficiency (its capacity to remain independent and prosper). We devote an important part of Chapter 6 to this topic. Finally, Aristotle made some key claims that have traversed the centuries (they are contained mostly in Book I of On Politics): that man is a 'political animal', meaning that it is made by nature to live in a political community, hence the state itself exists by nature; the polis - the political community, patterned on the city-states of ancient Greece but by extension the state in general - is the ultimate form of human organisation and exists to satisfy the highest goals of human life; the polis shelters all the other associated forms of human life, from families to businesses; and it alone should be governed 'politically' (Ryan, 2012, p. 83). For Aristotle the political community is distinguished from all other forms of social life and the notion of 'political' pertains in its proper sense only to the state. Interestingly, this may represent a point of differentiation between 'Western' conceptions of politics and Confucian ones, which may tend to see the state as an extension of the family and other forms of social life, rather than seeing the state as pertaining to a higher order than the other forms of associated life, as in Western conceptions shaped by the bequest of Aristotle.

For reasons of brevity we skip here both the philosophy of the Hellenistic period (which includes major philosophical schools such as cynicism, the Epicurean school, stoicism, scepticism - all in uppercase to stress that the contents of these philosophies are quite distinct and different from the meanings given to the respective terms in contemporary everyday language) and Latin philosophers like Lucretius and Cicero, but we cannot miss out a reference to the last ancient Greek philosopher, Plotinus (205-70 AC), who elaborated a very original and ambitious philosophical system whose influence lingers throughout the centuries.

The starting point of Plotinus's philosophy is what he called the One. The One is not the one of mathematics, rather the supreme principle of unity. Plotinus was in fact the first to ask the question 'why the Absolute is, and why is it what it is?'. The answer is that the Absolute poses itself. He theorised the One as causa sui (cause of itself), the Absolute that poses itself and in which necessity and free will totally coincide. He also conceived of the absolute as infinite, of which nothing can be predicated (this too being a point at least partly novel in Greek philosophy); the absolute is beyond being, thought, life - but is the cause of them all, as super-being, super-thought, super-life (the term 'super' being used in the Latin sense of 'above' or 'beyond'). This poses the problem of how all things derive from the One. Plotinus introduced forcefully into the philosophical debate the question of unity and multiplicity, of the relationship between the One and the Many, which has since permeated philosophical investigation. The answer furnished to the question of how the many derive from the One is that this occurs by hypostasis or procession. The 
argument, in a very schematic way, is as follows. The One can only think, or better contemplate, itself (although Plotinus warns against referring to the One as 'it' - nothing can be said that is predicated of the One). The rationale for this, put in a very rough way, lies in the One - the absolute unity - having nothing outside of itself. By thinking (contemplating) itself, a distinction is introduced between thinker (contemplator, the subject) and thought (contemplated, the object) - the totality of thought, that is, the world of ideas of Plato is thus posed through a hypostasis of the One. By posing itself the One also poses the other from itself. Plotinus develops here on Aristotle's idea that thinking is inherently an activity of contemplating, and contemplating is inherently creating, albeit in a sense partly different from the notion of creation in Christianity. This is what he called the Nous - translated as Intellect or Spirit, depending on what emphasis is given, whether more philosophical or more religious; we will refer to it here as Intellect. The Intellect is being par excellence, thought par excellence, life par excellence - but the Intellect cannot be the ultimate reality because of the duality of subject and object, of thinking/ thinker (the act and the agent: the active) and thought (the passive), which is inherent to it. The ultimate reality must be above it, that is, the ultimate reality is the One. By contemplating itself the Intellect, in its turn, hypostatises itself in the Soul, which commands and orders all things and the universe. Although the Intellect is a life of eternal, immediate, simultaneous possession of all objects, ${ }^{5}$ the Soul is desire (thinking is itself desire; just as looking is a desire of seeing, thinking is an activity of apprehension, where apprehend is the root word in Latin for 'taking', and hence volition is inherent in thinking). By desiring to transfer downwards what is eternal the Soul does so in succession, it poses things in succession, and this continuous, restless succession is time (and so time derives from eternity, but eternity is beyond time). The Soul is life stretching and hence flowing into successive moments whilst being loaded with the past moments: it is time in past, present and future. By contemplating downwards, the Soul orders all things of the world, by contemplating itself it preserves itself, by contemplating upwards towards the Intellect, the Soul thinks (which is at the origin of its creative activity). It is in the Soul that there is plurality (the Many). Indeed, Plotinus distinguishes the supreme Soul from the particular souls: matter plays a role in it (drawing from Aristotle's thesis that forms are individuated by matter), but matter itself is the soul deprived of its link with the One, total deprivation of the positivity that is in the One; matter is absence of being, or at most the last tail of being. This idea will be picked up by the philosopher Henri Bergson (amongst others) when he refers to individual living beings as an arrest of the flow of life and to spatiality as the arrest of the activity of the conscience (see Chapter 3 ). The possibility to contemplate upwards enables the Soul, and each soul, to return to the One (to the supreme unity). This occurs not like in Plato through 'Eros' (love) or in 
Aristotle through virtue, but rather through ecstasy, that is, by dispossession of any alterity (hence any duality or multiplicity), as the only way to achieve the infinite accretion of the self is by dissolving the self into the One, by undertaking the abandonment of the individual alone on her/his own (the sole individual) to the Sole (the One).

Plotinus's philosophy represents an inexhaustible fount of ideas (consider the inexhaustible implications of understanding of thinking as contemplating, creating, desiring) and a powerful reminder of what Greek philosophy meant when claiming that 'the horizon of being is the horizon of thought': one of the major achievements of Greek philosophy.

Implications for PA/Relevance for Philosophy for PA: a large number, probably most of the key conceptual tools that are being used across all the branches of knowledge, thereby including the modern sciences, have been elaborated and, often, brought to the utmost levels of perfection in the Classical Age of the Greek civilisation. By way of example, the very notion of causality and the conception of knowledge as 'understanding the causes of things' - which underpins so much of modern inquiry that calls itself 'scientific' (knowledge that is achieved through rigorous methods) - has been wrought out by the Greek philosophers, notably Plato and Aristotle. The application of these conceptual tools from philosophy may be developed in even more direct a way for the field of PA, which is far from having become an independent science with its problems unproblematically stated and its concepts and methods of inquiry uncontroversially standardised. An example is the usefulness of revisiting the four causes elaborated by Aristotle as a coherent system, whereby in the field of PA (like e.g. the field of international relations) it is also the final cause and the formal cause - not just the efficient or the material cause - to be meaningfully employed for the progress of knowledge in the field (this point is widely elaborated in Chapter 6). Importantly, the very branch of political philosophy as a distinct area within philosophy has been established and has taken form through the works of - most notably - Plato and Aristotle. Chapter 5 discusses the application of political philosophy more systematically to the field of PA, notably by focusing the issue of 'legitimacy', what makes a political system - and, as part of it, public governance and public administration - 'just' and hence 'acceptable' for the members of the political community (i.e. for the administered). Finally, ethical issues become centre stage, especially during the Hellenistic period, sowing the seeds for the development of the 'virtue' discourse and the key question of the significance of the practice of virtuous behaviour for the quality of public governance. 


\section{PATRISTIC PHILOSOPHY}

The Patristic philosophy was elaborated by the 'Fathers of the Church' (patres is the plural for 'father' in Latin, hence the term patristic) during the first centuries AC. Believers in the Christian revelation, they strove for elaborating a deeper understanding of the revealed faith - the Christian theology - and by doing so they also carried out a powerful synthesis between Christian revelation and classical Greco-Roman philosophical thought. With the spread of the Christian faith across the expanses of the Roman Empire, which in the first centuries AC stretched from nowadays England to the Middle East, from Central Europe to the Sahara Desert, encompassing all the Mediterranean basin, the (Judeo-) Christian cultural and philosophical revolution occurred and informed Western philosophy and culture forever.

We dwell here briefly on some of the tenets of the Christian revolution of special significance for philosophical speculation. First, the very notion of monotheism, the affirmation of God as 'the only one' ('Thou shalt have no other gods', states one of the Ten Commandments proclaimed in the Bible, Exodus 20:3 = Deuteronomy 5:7); a theological stance radically diverse from Greco-Roman polytheism. Second, the notion of the absolute transcendence of God (hence of Being). God is conceived of as totally 'other' from the world in a way that differs from the horizon of the Greek philosophical speculation, which tended to see the entirety of reality - both ideal and material - within the horizon of immanence (with the partial exception of Plotinus's thought). Third, the very notion of creation, that is, that entities are created by God out of nothingness. In this perspective, being is gifted to entities, entities are brought into being by Being (God): this is a perspective that in a sense overcomes the argument by Parmenides that 'Never shall this prevail, that Non-Being is': non-being is not, but entities - things that are - can come to being out of nothingness, and this occurs through an act of creation.

If these notions are novel to the Greek thought, at the same time the Greek thought contributed to shape the way in which the Christian revelation was culturally informed and propounded. When Christ is referred to as 'The Logos', as in the most famous prologue of the Gospel According to John, the findings of Greek philosophy should all be taken into account in interpreting the meaning of the words used by John (John's Gospel is written in Greek): the Logos is the 'Word', and notably the most important word in any statement, that is, the 'Verb', but logos in Greek is also reason and the order of things, as we already saw in Parmenides: 'the same is being and thinking, the same is thinking and what thinking is in function of, because without being, in which it is expressed, you will not find thinking: in fact [thinking] is or will be nothing outside of being' (Parmenides, Fragments, B8). Being and logos as reason are 
interpenetrated; they are the same. When John refers to Christ as The Logos in the perspective of creation ('all that was made, was made through Him'), from a philosophical standpoint he entails that the very being of all things is one with the Person of Christ.

The Trinitarian conception of God has had huge implications for philosophical thought. In Christian theology God is conceived of as one substance and three Persons, who in the order of the relation are the Father and the Son and the Holy Spirit, in the substance are one and only one substance. Later theological and philosophical speculation elaborated on the Trinitarian mystery conceiving of the nature of the Trinitarian relation as person. (Thomas Aquinas conceived of the relation of total and absolute love between the Father and the Son as having itself nature of person: the third Person of the Trinity - the Holy Spirit - is the total and absolute love between God the Father and God the Son; theologically and ontologically, total and absolute love $i$ S Person.) St Augustine [one substance, three persons that according to the category of relation are the Father and the Son and the Spirit], the German philosopher Leibniz, in addressing the Trinitarian mystery, wrote of 'an entity, by which an entity is related to an entity' - the persons of the Trinity are entities that cannot exist without other entities, hence essentially relational (see the important work on the Trinitarian theology of Leibniz by Antognazza, 2007). The category of relation, encountered in Aristotle as one category of being, becomes central in philosophical reflection in and through theological thought: this may have sown the seeds of much of modern intellectual thought, including the non-theological one, in which the category of relation is centre stage. The turn in the 17th century from the quest for the substances of things, which characterises all classical philosophy throughout the Middle Ages and Renaissance and was still present in 17th century rationalists, to the search for relations that features so prominently in modern and contemporary philosophy (see Chapter 3) - relations between things (the search for functional relations between phenomena is a key trait distinguishing the natural sciences since the scientific revolution of the 17 th century from the previous approaches to the study of nature) and relations between the subject and the object of knowing may be argued to have been profoundly affected and informed by centuries of theological reflection on the mystery of the Trinity.

The faith in the incarnation of God in history in a man, Jesus Christ, brings with it a revolution in the conception of the human being. For the GrecoRoman culture, the human being was simply a part of the totality and did not occupy any special place. It had a distinctively rational nature (the possessing of rationality singled out humankind from all other living creatures), but this distinctive trait did not endow humanity with a special place in the world. The Greek civilisation placed the human race as part and parcel of the cosmos, of the general order of the universe. With the Christian revolution, the human 
being becomes central in the history and order of the creation (as we shall see, with modern philosophy the human mind as the subject of knowing will enjoy a special place and will become for many philosophers the starting point of philosophising). This entails a radical anthropocentrism - the 'special place' reserved to mankind, chosen and loved by God in a special way above all other creatures. The human being is conceived of as free, and with a special possibility: to adhere to the will of God. The capacity to adhere freely to the will of God makes each and every human being occupy a special place in history, which, in the Christian perspective, becomes the history of salvation.

The revolution of values brought about by the Christian faith revolves around the centrality of love (as charity and mercy): the Greek notion of love as éros permeating the philosophy of Plato - a form of love that somehow presupposes the lover to possess 'agency' and to be active in striving towards the object of love - is reinterpreted through the lens of the total gratuity, whereby each and every human being is first of all recipient of the love of God (mercy), is first and foremost passive, rather than active, and only by virtue of the received love becomes active (charity). Christian love, the sacrificial love, the love that donates itself totally, is indicated through the Latin word charitas and the Greek term agape - a notion of love different from the love of friendship (philia), the love that drives the desire of joining the beloved (éros) or even love as affection and empathy, 'liking' someone or something (storge). As part of the Christian tenet of the centrality of love, the care for each person - irrespective of her/his origin and condition - becomes a central value. The seeds of principles that the contemporary women and men hold dear, like the universality of human rights and of ensuing ambitious political-social and administrative arrangements, like the building of 'welfare states' or 'welfare societies' aimed at 'taking care' with a universalistic thrust of a wide range of needs of the human person from education to health and social care, have been sown by the Christian revolution.

Christianity also introduced a linear (rather than cyclical) conception of time. The Greek had different notions of time, and some philosophers (e.g. Anaximenes) thought of it as circular, the eternal recurrence of the same, a notion later picked up by Nietzsche when he advocated a revolution against Christianity and the restoration of the spirit of the ancient Greek, the 4th century BC Athens (see Chapter 3). In Christianity, time is linear and proceeds from an origin (the creation) to an end (the Parousia, the return of Christ on earth and the Final Judgement). It is also in St Augustine that the conception of time as pertaining to the subject rather than the object becomes a central question in philosophy.

Christian theology brought about a new way of conceiving of evil (the giant of Patristic and paramount figure of spiritualism St Augustine elaborated an interpretation of evil as the absence of being: if all that is has been created 
by God, then it must be good, and evil as the absence of goodness has consequently the ontological status of non-being) that has since permeated Western thought (see notably Augustine, 397/400).

Implications for PA/Relevance for Philosophy for PA: Christianity has permeated every aspect of Western civilisation and as part of it Western philosophy (the main subject of this book), hence it is nearly impossible to single out specific areas which may track the influence on the Christian revolution on PA more specifically. However, if one is to be pointed out, this would probably be the notion of charitas as gratuitous and absolute love: this conception underpins notions of benevolence and the caring for each human being which has shaped such a large part of the ways in which public services have been governed and provided over the centuries, at least in the Western world (and in many regards later on 'exported' though the massive forms of policy transfer effected by Western colonialism). Moreover and also crucially, however impressively complex the question is, it may be claimed that key intellectual roots of modern age 'universal human rights' and contemporary notions of human person have been shaped by the Christian conception of love, and, as a manifestation of that, that the deeper and longer term roots of social rights and the welfare state/welfare society also lie to a significant extent in the spread of the Christian conception of love as charitas.

\section{MEDIEVAL PHILOSOPHY}

We start our brief tour of medieval philosophy with the work of Anselm of Canterbury. Born in Aosta, located in the north-west of today's Italy (and for this reason also known as Anselm of Aosta), he was monk, prior and abbot at the abbey of Bec, in the south-east of England. A distinguished theologian and philosopher, he was also involved in a dispute over a question destined to dominate medieval philosophical thought: the dispute over the nature of the universal concepts (see later). He worked out a proof of the existence of God that would enjoy an extraordinary longevity. The gist of the argument is that God can be defined as

something than which nothing greater can be conceived ... But for sure, that than which nothing greater can be conceived cannot exist in the understanding alone. For suppose it exists in the understanding alone: then it can thought to exist in reality, which is greater ... therefore it is beyond doubt that there exists, both in the understanding and in reality, a being than which nothing greater can be conceived. (Proslogion, c.2, reported in Kenny, 2010, p. 478)

It is the very concept of God that makes it certain that it exists. In fact, whoever denies the existence of God must have the concept of God, otherwise he would not know what he is denying. If he has the concept of God, then he is con- 
tradicting himself in denying it, because the very concept of that than which nothing greater can be conceived implies that it exists also in reality, which is greater than existing only in understanding. This argument has been called the ontological proof of the existence of God. In working out his argument, Anselm also introduced the notion of imaginary world, the idea of other possible worlds than the one in which we happen to be, to argue that God must exist in the real world. Both the ontological proof and the methodological idea of conceiving of alternative possible worlds to speculate about the property of this one would endure the centuries and are still matter for lively philosophical and theological debates.

We can now turn to a major figure of philosophy: Thomas Aquinas. Most of his work is developed in the Summa Theologiae, a systematic investigation and discussion of key philosophical and theological themes, and also the Summa Contra Gentiles. The style adopted in his works provides the author and us readers with rigour and self-discipline in the line of argumentation (Kenny, 2010, p. 309): an introductory set of challenges or difficulties against the position in favour of which Aquinas intends to argue are introduced (usually a triad). These objections to the thesis argued for are followed by a consideration on the other side (introduced by Sed contra: 'Against this position', or 'But on the other hand'), usually drawn from an authoritative text. After this, the main position propounded by the Aquinas is developed. By adopting this style, in developing his main position the Aquinas has to systematically engage with the contrary positions of which the reader is aware and whose rationale and underpinnings had initially been introduced. A thorough exercise of self-discipline, which is carried out throughout the discussion of virtually all the major philosophical themes - from the existence of God to the conditions of knowledge to the roots of human liberty - wrapped up in a work (see Aquinas, 1258/1264) which amounts to more than 2,000,000 words!

A key notion in the philosophy of the Aquinas is the differentiation between essence and existence, which coincide in God and are distinct in all the entities. The essence is the 'what it is' of a thing, its form: it is basically the Aristotelian conception of form seen above: what gives something the form that makes it to be what it is. If in God essence and existence coincide (because God is being, it does not have being), for any other entity essence does not identify itself with existence. This means that those things that exist could also not exist and, equally important, could also never have existed, and could not exist anymore in the future: they are contingent. The world as a whole is contingent: it may be or not be. The world does not exist by its own virtue, but by virtue of something other, whose essence is identical to its existence: God. It is for this reason that Aquinas's philosophy has been called the metaphysics of the actus essendi, of the (contingent) 'act of there being'. This metaphysics purports the metaphysical contingency of all entities: they receive and partake 
of being, they have being (that is, they are) because they have received (passive stance) being and participate of it. This is a conception that relies on the notion of 'analogy', which plays a central role in Aquinas's philosophy: the participation to being by entities, whereby the cause (Being, in uppercase) leaves a trace of it in the effects (beings or entities), although entities only have being: they possess it, because they have been gifted the participation to being. Analogy entails that between the Creator and the created things, between being and entities, there is only a difference of grade: what is predicated of entities can also be predicated of God, albeit not in the same way or with the same intensity. Significantly, the cause of all entities is not necessitated in providing the existence: being is granted as a pure gift, and it is granted by the absolutely other (which entails the absolute transcendence between God and the created entities). In this perspective the key questions that philosophy addresses can be formulated as (see Reale and Antiseri, 1988, in particular pp. 424-5, Vol. 1): why being rather than nothingness (this a question at the centre of the philosophies of Leibniz and Spinoza; see later)? And why does being allow/ enable entities to be (this question plays centre stage in the metaphysics of 20th century philosopher Martin Heidegger)?

If all entities participate of the same being, because the cause (the Creator) has left a trace - an effect - in all things, then there is a fundamental comparability of all things amongst themselves. The intellect can detect similarities as well as dissimilarities between things, and hence it can make judgements about the things of the world by applying knowledge gained about one experience to other experiences, that is, through reasoning by analogy. Referring in an analogical way to one thing means that that one thing participates something of another one, albeit transcending it: but knowledge may be attained by analogy of a known thing to unknown things. Thus, another related way of employing analogical reasoning pertains to the sphere of the philosophy of knowledge: one way of gaining knowledge about one thing is by identifying profiles in which that one thing participates something of another one, has something in common with another one, which transcends the first. This notion has been widely used in theology, whereby knowledge of God or God's attributes may occur by analogy with things of this world, which, although completely distinct from God, may partake some properties - these properties being knowledgeable to human beings. ${ }^{6}$ Analogy, with varied meanings and underlying defining and epistemological claims about 'external validity', is also a central notion in many contemporary disciplines, whereby the claim is that knowledge may be attained by analogy of a known thing with unknown things. This also applies to the field of PA, where countless studies are implicitly or explicitly based on analogical reasoning: transferring knowledge generated in one domain to another domain, grounded on commonalities of properties between the two. 
We return to reasoning by analogy in Chapter 3 when discussing issues of philosophy of knowledge, notably certain critiques to Popper's epistemology.

As it has clearly arisen, the distinction between potentiality and actuality is central in the philosophy of Aquinas. ${ }^{7}$ All entities of the world, all events of history may be but also may not be. Apart from God, whose essence also entails the existence, all other things are simply a potentiality to being, an attitude to exist ('id quod potest esse', 'that which can be'). The potentiality-actuality distinction is of crucial significance not just in the realm of metaphysical speculation: this notion is also central in any realm of the individual and social life, and hence notably, for the specific purposes of this book, for all the applied disciplines such as management or public administration that aim at 'making things happen' (one definition of 'management'). The underpinning of this or any similar definition statement about management and public management is the distinction between potentiality and actuality, and how to transform the potential into actual. Leading scholars like Bardach (1998) noticed that in the social sciences, and notably in public administration and policy, there seems to be an inadequate treatment of the notion of potential (for example, what is the meaning of the claim that if a 'good practice' had one effect under a given set of circumstances, then it would make similar effects apparent under different circumstances? How do we deal with this 'potential to make change happen', and also how do we deal with the counterfactual arguments that a practice, which allegedly 'worked' in one case, 'could have had' another effect under only slightly changed circumstances in the other case?). Counterfactual arguments are crucial in many design sciences where the objective is to shape the world in a different way (by adopting a new management technique or a new public policy, by appointing a new 'leader', and the like) in order to achieve 'better' outcomes.

Another key distinction in Aquinas's philosophy is between ontological truth (adequatio rei ad intellectum dei: the adequacy of a(ny) thing to God's intellect) and logical truth, which concerns us as the subject of knowing: the adequacy of our intellect to the thing (adequatio intellectus nostri ad rem). The notion of 'truth' is a widely debated issue over the history of philosophy: Aquinas's position, following Aristotle's, is that the criterion of verity is the correspondence of the concepts in the intellect with 'how things are' - although this does not mean that the concept is the thing, but simply that correspondence to things is the truth criterion.

Aquinas was an influential intellectual of his time, but he also had an incredibly powerful afterlife in the form of a philosophical school of thought, called 'scholastic', which continued for centuries and still is alive, generally referred to as neo-scholastic; this stream of thought has been developed over the centuries based on the body of philosophy elaborated by St Thomas Aquinas. Philosophers belonging to the scholastics are also called 'schoolmen'. 
Implications for PA/Relevance for Philosophy for PA: like for Classical Greek philosophy, medieval philosophy has provided a huge repertoire of conceptual tools that permeate knowledge generation - notions that can probably more easily be applied in a direct way in a field of inquiry that is far from having become an independent science with its problems unproblematically stated and standardised methods. More specifically, we revisit neo-scholastics and possible implications for PA in Chapter 4, notably in relation to the key notion of the distinction between potentiality and actuality.

\section{THE DISPUTE OVER THE UNIVERSALS AND ITS CONTEMPORARY SIGNIFICANCE}

A philosophical dispute that raged during the medieval time, and whose significance hasn't lost its actuality, is that over the nature of the universals ${ }^{8}$ - a problem whose terms are fraught with implications also for the more circumscribed purposes of our book, namely outlining some path(way)s for more systematically employing philosophy into PA. The matter of the dispute is the foundation of universal concepts intended as terms predicated of a multiplicity of individual things, for example 'human being' or 'animal'. It regards the issue of whether universals are real (of which there are two versions: they do exist as ideal objects, more a Platonic position; or they are the product of a procession of abstraction by reason, but yet only individuals are real in the proper sense - Thomas Aquinas) or not. The latter position is called nominalism: universals are only nouns (flatus vocis, the utterance of voice). The dispute over universals produced an incredibly lively debate during the 12th, 13th and 14th centuries. Giants in this debate were scholars Guillaume de Champeaux (in English: William of Champeaux, 1070-1121), Pierre Abélard (1079-1142), Roscelin of Compiègne (Latinised as Roscellinus Compendiensis or Rucelinus, 1050-1125), St Bonaventure (1221-1274), Robert Grosseteste (1175-1253), Joh Wycliff (1320-1384), St Thomas Aquinas (1225-1274), William Ockham (1285-1374) and John Duns Scotus (1265-1308).

The first position is that of (radical) realism, initially stated by William of Champeaux: universals are metaphysical entities actually subsisting. The problem with this position is that if universals exist as things (albeit conceptual things), then all individuals should be the same, not just in the sense of having the same characters (like Siamese twins), but exactly the same (what else explains the mingling with haphazard elements?). More subtly, the objection (e.g. in Pierre Abélard in Le Pallet, 1079 - Chalon-sur-Saône, 21 aprile 1142) is that the universal for its very nature is something that can be predicated of a plurality of entities (in Latin: quod notum est predicari de pluribus). If this holds, it cannot be a thing in itself, an objective entity which, as such, cannot be predicated of another entity (in Latin: res de re non praedicatur). On a more 
evaluative rather than analytical note, it may be reckoned that the individual would be fundamentally de-valued if it were not an individual, if each individual were at most a manifestation of one and the same universal thing.

At the very opposite we find the position of (radical) nominalism: nothing exists beyond individuals (in Latin: nihil est praeter individuum) - universals do not exist, what remains of them is the physical utterance of a voice. For this position universals are at most vague labels used to classify objects - but they cannot be predicated of things (they don't say anything of what a thing is, 'of what which is in common with a class of other things', to use a modern-day terminology drawn from the study of logic).

A third position called moderate realism can be delineated as follows. It is individuals that exist, but reason can distinguish, separate and, in a sense, abstract the characteristics that qualify and are in common to all individuals of the same species. It is on these elements in common (similitudo or status communis), as captured by the mind, that universals - universal concepts and notions - are founded. Universals are concepts. They lie in the mind (of human beings, as God's intelligence may differ), and signify the status communis, the common elements or properties that qualify a species or category of individuals (the common properties of all human beings, or of all dogs, or of all Total Quality Management systems, to hint back to Pollitt's example recalled in Chapter 1, because the notion of universal concept applies not only to 'natural' entities but also to man-made entities, artefacts like the deliberately engineered social systems for the running of a public organisation, like a strategic planning system, a management accounting and control system, a human resources management system, a Total Quality Management system, and the like).

Another way to formulate the problem is whether universals are ante rem (first universals exist, then things are made as copies from that pattern); post rem (universals exist only in the mind that abstracts them, if they exist at all), or in re (universals exist only in concrete individuals, from where they are abstracted by the mind) (Reale and Antiseri, 1988, pp. 396-400).

The dispute over the universals continues to our days, often intermingling with the issue of how to interpret Plato's ideas. Logicians and analysts of language have tried out a variety of approaches: Frege's propositional logic and predicate calculus; the theory of classes; the notion of ideas as paradigms, and so on. However, it seems that in crucially important respects the basic terms of the problem are still the same on which medieval scholars debated quite a number of centuries ago.

Implications for PA/Relevance for Philosophy for PA: as widely discussed later in the book (Chapter 6), the actuality of the medieval debate over the nature of the universals is witnessed by the observation that where a scholar stands in that debate may be closely linked to where s/he stands in conceiving of the social sciences in general and of public governance specifically. Realist 
positions in the conception of the universals appear hardly compatible with radical social constructivism, which tends to be aligned with a nominalist conception of the universals, and it appears the opposite may also hold: nominalist positions in the conception of universals are difficult to reconcile with realist positions across the whole gamut (we refer the reader to Chapter 6, where contemporary social constructivism and critical realism in PA are extensively discussed).

\section{LATE MEDIEVAL PHILOSOPHY}

If the scholastic philosophy tended to dominate the 13th and 14th century, the criticisms moved it to pave the way to a 'crisis' of the entire medieval philosophy and, later, to the dawn of the philosophy of the modern age. Such crisis was triggered also by the critiques formulated by John Duns Scotus and especially William of Ockham.

Scotus advocated taking simple or univocal concepts as the starting point of philosophising, and claimed the univocal, individual entity to be object of intellection (his writings are collated in Duns Scotus, 1950). ${ }^{9}$ Taking a differing stance from analogical reasoning, he claims that transcendental predicates are univocal, not analogical, and transcendental disjunctions apply to whatever there is: every being must be either actual or potential, either necessary or contingent, either finite or infinite - and this property of transcendental disjunctions to be univocal applies to God as well. (As we shall see later, Kant turned this perspective upside down and located transcendentals in the mind of the knowing subject, rather than as properties of being as such.) Scotus also introduced a subtle distinction between subjective and objective potentiality. Subjective potentiality is for Scotus what the Aristotelian notion of potentiality is about: for Scotus, Aristotle by potentiality intended the potentiality of the 'subject of the power' to become something (the potentiality is 'endowed' to whoever or whatever holds the power of becoming something), for example an embryo can become a child, a child an adult human being, and so forth. Objective potentiality occurs when something receives the potentiality to become: it is the terminus (recipient) of the power as opposed to the subject of the power to become. For Scotus, things can also come into being as terminus of power held elsewhere. This paves the way to the notion of synchronic contingency: possibilities, not compatible in one world, are possible in different possible worlds - a notion employed by modern philosophers who have widely used the notion of alternative possible worlds. (Leibniz, who famously spoke of this as the best of all possible worlds, is attributed the introduction of the notion of 'possible worlds' into philosophical debate, but the roots of this concept lie in the notion of objective potentiality introduced by John Duns Scotus, and before him in the structure of the argument formulated by 
Anselm to demonstrate the existence of God.) To gauge the significance of this notion, it may be considered that any time a counterfactual argument is used (arguments like 'what would happen/would have happened if something were different/had been different from what actually occurred?', 'what alternative outcomes would occur/would have occurred if something had been different from what actually happened?'), we are somehow resorting to the philosophical notion of alternative worlds, ${ }^{10}$ whose way was paved by Scotus's notion of objective potentiality. Counterfactual arguments are crucial in many design sciences (Simon, 1969/1981/1996), like PA, whose goal is taming knowledge for shaping the world in different ways in order to achieve alternative 'better' outcomes (e.g. what alternative outcomes may be attained by adopting a certain new public management technique or a new public policy, by appointing a new 'leader' at the helm of an organisation, and the like).

The crisis of medieval philosophical thinking is strongly associated with the critiques to the scholastic formulated by Ockham ${ }^{11}$ (see for key writings Ockham, 1985), and notably his criterion of investigation of reality known as 'Ockham's razor', which is stated as follows: 'entia non sunt multiplicanda praeter necessitatem', that is, 'you must not add any entity or notion that is not strictly necessary' (in order to explain something). It is a very 'modern scientific' approach to theorising whereby parsimony in theorising is highly valued. From his philosophy - whose corpus is obviously much wider than just the statement of the criterion of the 'razor' - it is entailed that we as human beings cannot know the essence of things, only the qualities or accidents of things that experience reveals to us (this is the starting point of much of the philosophical tradition of the empiricism, which will flourish in Britain). Nor can we know by analogy - there is a hiatus between finite and infinite, and only the pure act of creative will of God can link the two. Ockham goes the other way around than the ancient Greeks, at least in Plato's tradition because Aristotle has a differing stance on this, for whom the core question is: how does individuation derive from ideas (ideal archetypes)? Instead Ockham's position is that reality is 'all in the singular', only individuals are real. This position may of course be criticised - and it has been widely - but it had a huge influence on subsequent philosophical thought. Amongst his many contributions to philosophy, Ockham also introduced the distinction between mental terms (which is the same) and verbal terms (oral or written, which change across languages), a concept that prefigures the notion developed by the linguist Chomsky of the distinction between superficial and inner structure of a sentence (the superficial structure changes between languages and within a language, the inner structure is the same): a notion widely used in linguistic studies and that represent a major component of contemporary philosophical research work - as well as of discourse analysis, which is widely employed in the humanities and the social sciences alike. 
Implications for PA/Relevance for Philosophy for PA: like for medieval philosophy more widely, late medieval philosophy has furnished the modern scholar with key concepts that permeate knowledge generation, like the principle of parsimony in introducing notions when theorising or the notion of counterfactuals, which have a prominent role in PA inquiry.

\section{RENAISSANCE}

Situated between the medieval and the modern age, Renaissance as an epoch stands out, distinct from both medieval age and modern age. The Renaissance had its birth as well as its zenith in the Italy of seigniories, principalities and republics, and of the innumerable genial artists that operated in the peninsula during the period that spanned, approximately, from the second half of the 14 th century to the first half of the 16th century. From Italy, the Renaissance as a philosophical, artistic and cultural movement spread throughout Europe, in different waves and with highly varied impact. Also referred to as 'humanism', Renaissance put the human at the centre (intended not just as the human species, but all that is 'human'). It is a multifaceted epoch, immensely rich from a cultural viewpoint, where artists and literates are the main protagonists, possibly more than philosophers in the strictest sense, and here we can only touch upon a very few of the ideas that were delved into and debated across Europe during the Renaissance.

One is the idea of the vocation to perfection of human beings, omnipresent in humanistic writers: we will discuss its significance for government and public administration when we debate the role that virtues play in good government and good governance in Chapter 6. Another powerful idea, of clear neo-platonic imprint, is the notion that each human being is a micro-cosmos; it is the idea that all that is in reality is somehow reflected in each and every person: a powerful reminder that in investigating reality scholars always hold two options: alongside the option of 'watching out' to what is empirically detectable, scholars also always hold the alternative - complementary - option of looking inside oneself, into our own conscience and soul. For example, what is 'ethical' in the behaviour of public servants may be studied by observing actual behaviours, but also by deriving from our conscience what is meant by ethical behaviour, under given circumstances, possibly also thought experiments.

A third key idea is that of the immutability and universality of human nature, which is powerfully summed up in a key motto of Renaissance: homo sum: nihil human mihi alienum est - 'I am a human being, nothing that is human is alien to me' - meaning that each and every human being encapsulates in herself/himself the entirety of humankind. Key thinkers of this epoch who strongly argued about the immutability and universality of human nature are 
Machiavelli and Guicciardini. In the field of PA there are different positions on this theme, and the implications of the immutability, or otherwise, of human nature are of enormous magnitude for the way in which the discipline is studied and practised. One such implication is whether we can learn from history or not. Machiavelli argues that we can, and one underlying reason is exactly that human nature stays the same over time - which is not to say that it is impermeable to influence from the environment, but that the nature of mind and soul (the capacities to understand and the motives to act, when conditions allow) stay over time and across latitudes. Releasing this assumption may lead to very different inferences about what we can learn from history - indeed it may ultimately mean giving up the very possibility of learning from history.

Implications for PA/Relevance for Philosophy for PA: the education of the Christian Prince - hence the question of what skills and qualities are required of governors - has been central to Renaissance thought, which has thus furnished the posterity with reflections whose enduring value cannot be underrated about the 'profession' of governing and administering, and the requisite virtues and skills required for this purpose. Indeed, some of the key contributions we discuss widely in Chapter 7 for their contemporary significance and relevance to a range of PA topics - like The Prince by Niccolò Machiavelli and Utopia by Thomas More - are literary masterpieces of Renaissance.

\section{THE SCIENTIFIC REVOLUTION}

It does not appear an overstatement to say that the scientific revolution that occurred over the 16th and 17th century, and the ensuing Industrial Revolution of the 18th century, changed the world.

The two revolutions are deeply interlinked, and the philosopher Francis Bacon ('the philosopher of the industrial age') is probably its leading exponent: knowledge must be capable of helping practice, and he famously linked knowledge and power in the statement that 'knowledge is power'. Many of the tenets of 'modern' science were conceived during this epoch, by Bacon as well as physicists like Galileo and Newton, including the notion that knowledge is public (the procedures whereby knowledge is gained must be made public to ensure replicability), inter-subjective, progressive and cumulative (given the statement of problem and method, consistent accumulation of knowledge becomes possible), grown and tested through repeated observations. From this conception derived a different organisation of intellectual work and of the academy: one akin to our contemporary conception of knowledge production by groups of researchers studying similar problems with public methods of inquiry and repeated, precise observations. Knowledge, in this perspective, proceeds step by step from induction based on a larger and larger number of observations, and it does not rely on the authority of the past, in stark contrast 
with the primacy of the auctoritas, the idea of appealing to the authority of illustrious scholars of the past to justify a claim, which characterised medieval thought. Indeed, in the new intellectual ambiance of the scientific revolution the authority of the past may, and in a certain sense must, be challenged: 'Nullius in verba' ('nothing is in words') is the motto of the Royal Society of London for the Promotion of Natural Knowledge, chartered in 1662 by King Charles II and whose establishment was heavily influenced by Bacon's philosophy. Facts and experiments, ${ }^{12}$ not the authority of past thinkers - or the idola, idols, that society and tradition produce and that encumber the understanding of things - drive the way forward for Bacon and his contemporaries, in what came at the time to be termed 'scientific knowledge'. This is in many respects still the way in which not only the natural sciences but also the social sciences proceed - or at least this is the conventional term of reference propounded for how they should proceed, although alternative paradigms contend this claim (we will discuss the terms of this contention in the field of PA in Chapter 4).

Bacon also provided insightful views into the way in which the social context, within which scientific production occurs, may powerfully affect (and 'bias') the production of scientific knowledge. He may in this sense be attributed the qualification of the first sociologist of knowledge. ${ }^{13}$ Bacon also introduced the idea of the elimination by induction of false theories, in order to leave but one 'correct' theory. This is known as the experimentum crucis, 'the crucial experiment' or literally 'the experiment of the crux', as a way to call between two competing theories and discern which one holds and which one to discard. The episteme of this method for testing theories, however, was criticised by Karl Popper (on the ground that infinite alternative theories can always be produced, hence no experiment is really a test between two theories) as well as by Pierre Duhem and others (see Chapter 3). Indeed, in the natural sciences, and even more so in the social sciences, rarely can it be spoken of 'crucial experiments' that can decisively discriminate between two or more theories and attribute validity (albeit provisional) to one theory and rule out on a definitive basis the others.

Implications for PA/Relevance for Philosophy for PA: the modern conception of 'science' and scientific knowledge was conceived of in Europe in this epoch, and these notions remain the term of comparison for all endeavours to set up any 'science of PA' or the 'administrative sciences'. Although social sciences took off mostly a century later during the Enlightenment and the 19th century, many of the seeds of modern social sciences have been sown in this epoch. 


\section{EARLY MODERN PHILOSOPHY}

The commencement of early modern philosophy is often associated with the French philosopher René Descartes (see notably Descartes, 1637; and more widely the collection of readings in Descartes, 1998) and with his most famous approach of the 'methodological doubt', summed up in the statement: 'cogito, ergo sum' 'I think, then I am'. The statement is however crippled of a key component, the full statement being: 'I doubt, then I think (doubting being an act of thinking), then I am'. The doubting by the reflective subject becomes the commencement of philosophy because nothing else can constitute a 'certainty' from which philosophising can take the move. It is in this sense that Descartes has brought about the 'revolution of the subject' that characterises modern philosophy: the thinking subject is the commencement of philosophy (and for Descartes the only thing of which the thinking subject may be certain is its own doubting).

He also introduced a duality that is still haunting the contemporary man: the dualism materiality/spirituality, that has permeated the debate to our days, owes much to Descartes's distinction between res cogitans (literally 'the thinking thing', the thinking substance) and res extensa (literally, 'the extended thing', the thing whose defining property is to have an extension). It has been noted that this distinction, and especially the notion of matter as inherently defined by its having an extension, was profoundly attuned to the Newtonian physics that was emerging at the time, but is put into question by the developments of modern physics. The argument of Descartes in a nutshell is that what remains of every material object, after decomposing it, is its extension, and hence this is its 'substance'. But modern physics has shattered this perspective: the functional equivalence of energy and mass (stated by Einstein's famous equation), the indeterminacy of position and movement of small objects like atomic and sub-atomic particles, ${ }^{14}$ and recent (though contested) notions like dark matter and antimatter ${ }^{15}$ are all casting serious doubts on the property of extension as being the qualifying feature of matter.

However, Descartes's conception of the universe as made of simple, dull matter everywhere, without ends (in both the finalistic sense and the physical sense), without borders and without purposes was a perfect fit for the way in which Newtonian physics was progressing, and the way in which it was getting rid of medieval and Renaissance notions of nature. Nature is in this conception not made of substances to be known, it is just matter whose relations and interactions can be measured, that are entirely expressible through mathematical formulas. The discovery of such mathematical formulas was the task of physics. It is at this time that physics becomes the 'second discipline' in ranking after philosophy. In this epoch physics and philosophy become the 
trunk and the roots, respectively, of knowledge, with all the other disciplines being placed in a subsidiary position. During this period the idea also arises that animals could be just machines (Descartes added a question mark to the statement: it was a question he posed, not a claim he made). In this dull world, the human being is singled out as unique amongst living beings because it is the only one to be made of two substances at the same time: the thinking thing and the extended thing. ${ }^{16}$

Descartes, like other constructors of novel metaphysical systems like Spinoza and Leibniz, can be ascribed, broadly speaking, to the camp of 'rationalism', at least in the very basic sense that they make the assumption that ideas are at least partly innate and hence that reason can proceed, to some extent, 'on its own' in knowing the world. In this scheme, the camp opposite to that of rationalism is empiricism, where this means assuming that all ideas derive from the senses. This is by far an oversimplification, but somehow may serve the purpose of shedding light on one key point distinguishing diverse philosophies: those belonging to the camp of rationalism and those in the camp of empiricism. The distinction between rationalism and empiricism lingers and appears far from being overcome, and today scholars still tend to fall (though not squarely) into either camp (in the field of PA, this point is stated by Riccucci, 2010; see Chapter 4 in particular where she works out a classification of the philosophical stance of contemporary public administrationists).

We can now turn to the other builders of great metaphysical systems of the 17th century: Spinoza, Leibniz and Malebranche. Baruch Spinoza was the philosopher of 'pure necessity' and the immanence of all in God; Wilhelm Gottfried Leibniz of the transcendence of the absolute Being-God.

Spinoza (for an English edition of his main works see Spinoza, 1951; see also Spinoza, 1677) is rationalist in that his philosophical thought commences from one idea that does not derive from experience: there is only one substance, this is God - the demonstration of whose existence occurs along the lines of the ontological proof - and all the rest is derived according to the criterion of absolute necessity. In this perspective, nothing exists that is contingent, and hence nothing exists outside of God. This position may be classified as belonging to pantheism (all is God) and monism (there is only one substance). For Spinoza, the res cogitans and res extensa are just two out of infinite attributes of God-Being (God as the totality of being). The assertion of the category of necessity as the 'dominant property' of Being is part of the bequest of Spinoza that will have a huge influence on later modern philosophers, notably Hegel (whose philosophical system also owes to Spinoza the pantheistic vision, although for Hegel it is more appropriate to talk of panentheism: all is 'in' God). Classical metaphysics relied on the transcendental disjunction: something that is, either it is necessary or it is contingent. It did not claim that 
one of the two would be the only 'dimension' of Being. Spinoza instead leans towards asserting that necessity is the only category of being.

Leibniz was a genial thinker, active in governmental roles for most of his life, and his philosophical intuitions furnished a wealth of materials for philosophical speculation over the centuries. It is only recently that the majority of his writings have become available, and recent discoveries have shed new light on this genial thinker (see Antognazza, 2009, 2016; for a previous collection of his writings translated into English, see Leibniz, 1988).

Leibniz developed an original philosophical system: the theory of monads (a philosophical system which at face value is quite hard to come to grips with because it is far from intuitive, especially for the contemporary man not plunged into the culture of the epoch). Monad is a word of Greek origin for unity, and it has its roots in Aristotelian notions, notably the notion of form (which we have already encountered and that refers to 'unity and order' as the essence of a thing) and the notion of 'entelechy' as the becoming actual of what is otherwise only potential. Such notions are reinterpreted by Leibniz in original ways by conceiving of Monads as whole worlds or micro-cosmos (an idea of neo-platonic origin that enjoyed wide currency during the Renaissance). For Leibniz, reality is made of monads, whole worlds interconnected (harmonised is the term used by Leibniz) amongst themselves by God. Importantly, for Leibniz reality is made of whole things, intended as objects of intellection: thus, a human being is not made by the cells, molecules and atoms that compose her/him at a given moment: this is a spatial understanding of things - but for Leibniz a human being and a cell are two different objects of intellection, and as such they co-exist next to one another, harmonised by God, rather than 'composing' one another in relations of parts and wholes. Leibniz also made an ingenuous attempt to harmonise modern physics (to whose development he himself contributed) and metaphysics, endeavouring to pursue a synthesis that was probably never attempted any more in modern times after the passing away, in Hanover in 1716, of the Philosopher of Leipzig.

Methodologically, Leibniz asserted (assumed) that certain principles, like the a priori principles of non-contradiction and of sufficient reason, are innate, and therefore he may be firmly ascribed to the camp of rationalism.

Nicolas Malebranche is regarded as the main exponent of the philosophy of occasionalism (a stream of thought with a long history in both Christian and Islamic thought, also in relation to the central question of explaining God's miracles and the 'disruption' they bring about to the 'natural' cause-end-effect chains): centred on the idea that God (as natura naturans, shaper of everything) is the one and only true cause of everything (natura naturata, nature as created), occasionalism is critical of the causal power of creaturely causes, and in its purest form (global occasionalism) treats all other causes as at most 'occasional' (thence the name of 'occasionalism') and God as the only genuine 
cause of everything, while in more moderate forms (local occasionalism) it allows in certain domains of reality for creaturely causes to exercise their power, while always upholding that God is the ultimate genuine cause of all (a systematic review of the philosophy of occasionalism, to which we refer widely here, is elaborated by Lee, 2008/2019). The main underpinning of occasionalism is the argument about conservation of the created world to lie in an 'act of continuous creation' by God. In a nutshell, the key question here is how the world is kept into being (conservation) by God: if this occurs through a direct, non-mediated act of continuous creation by God, then in the strongest sense God is the only and genuine cause of everything - the logical alternative being that if it suffices that God 'merely conserves' things into being, then these creaturely things can wield causal power over each other (and hence their influence cannot be reduced to that of merely occasional causes); intermediate positions may explain forms of local occasionalism.

The nuts and bolts of the philosophy of occasionalism (Malebranche, 1997) can be better appreciated when set in the context of the 17th-century debates on mind-body interactions triggered by Cartesian philosophy, with questions dominating the debate like: what is the causal power of bodies (the extended things) on the thinking things, and vice versa? Or do extended things only have causal powers on other extended things, and thinking things on other thinking things? And so forth. To better set in perspective occasionalism, it is meaningful to ponder on the logical alternatives to it (Lee, 2008/2019): Cartesian interactionism, allowing for creaturely causes to wield power on each other, and Leibnizian 'pre-established harmony', whereby substances (monads) only wield causal power on themselves, while it is God's harmonised order of the universe to enable change to occur in a coordinated fashion amongst substances (Leibniz held the view that finite substances do not have the causal power to bring about change in other substances, though they can be causally active in causing their own successive states).

We can now pause for a moment and reflect on the directions that philosophy has taken at the dawn of modern thought. From Descartes, via Spinoza, Malebranche and Leibniz, to Hegel we witness in continental Europe the development of the great metaphysical systems. These philosophers are not just attempting to criticise or integrate previous metaphysics (mainly, Plato's and Aristotle's metaphysics) as most medieval philosophers have been doing. Rather, they strove to re-establish metaphysics through a new system that attempts to supersede all the previous ones. The same thrust is shared by Kant, although his direction is in a sense the opposite: not to establish a new metaphysics, but to draw the limits of any future metaphysics (as testified by his significantly titled work Prolegomena to Any Future Metaphysics That Will Be Able to Present Itself as a Science). What we here behold are attempts to a radical re-foundation of philosophy. These attempts were mainly continental 
European, notably in France and especially Germany. On the other hand, British and American - Anglophone - philosophy took a different direction, more in continuity with the idea of criticising and integrating previous philosophies than re-founding the whole philosophical discourse. The roots of much of Anglophone philosophy are probably to be found in empiricism. It is to this stream that we now turn.

\section{EMPIRICISM}

Empiricism is a philosophical strand central to the development of both natural and social sciences (and that should be kept distinct from its 'offspring' known as positivism, which we discuss later), and it is a mainstay, it almost embodies a 'stance' that constitutes a multifarious and yet central stream of thought for the field of PA (see Riccucci, 2010, who neatly distinguishes empiricism from positivism and its neo- and post-variants).

Some of the roots of empiricism can be found in the critique of the knowability of the 'substance' by the human mind, already surfaced in Ockham and, in different terms, in Scotus. ${ }^{17}$ It is a central theme in John Locke's Essay Concerning Human Understanding: substance, intended as what underlies and sustains ${ }^{18}$ what we can perceive through the senses, is, he claims, unknowable (it may be noted that Locke does not deny the existence of the substance, but rather its knowability). This argument is in many respects a precursor to Kant's conception of substance (he will use a different term: 'noumenon') as the pure limit to human reason; the unknowable, but yet necessary, limit of knowledge. Knowledge for Kant and for Locke can only be developed on phenomena - for Locke knowledge is knowledge of those properties of things that manifest themselves 'empirically' and that we capture through the senses. This is a key claim of Locke's philosophical contribution, although we should immediately alert the reader that the analysis of how human knowledge unfolds, developed by the English philosopher, is far more articulate and sophisticated than this bare statement. His influence on subsequent developments of philosophical and scientific inquiry can hardly be exaggerated, because much of modern philosophy distanced itself from the search for the substance of the things and concentrated instead on what of their properties is knowable. In a certain sense, much of modern philosophy has adopted the basic stance, if not the specific terms, of Locke's philosophy (his writings are collated in Locke, 1975).

This central statement of the Essay has been the target of harsh critiques. The question is whether the notion of substance as 'what sustains' is a pertinent depiction or rather a caricature of what classical metaphysical philosophers meant. Is 'that which sustains' what Aristotle or Aquinas meant with substance? Or is it rather essence, the form of things that they meant with substance? For example, dad, mum or our partner in classical metaphysics 
'are' first and foremost persons, and then they also hold qualities like having an extension, having a colour of their skin or their eyes, and so on, and they are not just a collection of perceivable properties (their extension, colour of skin and eyes, etc.)? These properties are not the whole, or indeed the essence of mum or dad or the partner, who are persons. Substance in classical metaphysics may well be something different and more than just 'what lies under and sustains'. And so, we are back to the fundamental question: is the idea of substance to be tucked in the category of the useless, or of the useful? As the reader will guess, the question is not over and the issue of the human possibility of knowing the substance of things resurfaces in different guises in different epochs, from idealism and neo-idealism to phenomenology, as we shall see in Chapter 3.

Another key author of British empiricism is Hobbes, who developed a metaphysics of corporeism. Hobbes is famously associated with the notion of the state as a 'Leviathan', a theory of the state developed is his homonymous work Leviathan (1961/1996). The Leviathan is a sea monster (referenced in the Old Testament) to which Hobbes likens the state as a necessary evil. Given that human beings are mutually a potential life threat, the only remedy that can realistically be deployed lies in the concentration of the monopoly of the force into an impersonal entity, the state. The state, a produce of human beings, is inherently 'invasive' into individual liberty, and yet in its absence the world would be worse because it is the sole guarantor of the possibility of a relatively safe life (in Locke, another essential function of the state is also as guarantor of the safeguard of private property). We will return to the political philosophy of Hobbes in Chapter 5, in relation to the notion of a 'social contract' perspective to the foundation of the legitimacy of a political system. Here we notice how Hobbes's argument still lurks ubiquitous in contemporary politics and PA studies: is the state invasive of the private sphere, or do private organisations like businesses and corporations have the upper hand and capture the state (or the portions of it that are of interest for the pursuit of their own interest)? Does the state 'invade' the private sphere in overall equitable and fair ways, or rather inequitably and unfairly (e.g. by treating people differently from different social and ethnic groups)? These and related questions recurrently surface in the field. Hobbes's critique may elicit pertinent and yet at times forgotten questions. Let's take by way of example the practitioners' as well as academic's debate on the benefits and challenges of 'joined up government', 'whole of government', 'holistic government', and the like. It is widely held that a more coordinated government would almost by itself be beneficial, but from the perspective of Hobbes's critique, wouldn't a holistic government, empowered with modern technologies of collection of personal data and coercive means unthinkable at Hobbes's time, also be a major threat to individual liberty? And what if government is not democratic or respectful of human 
rights, with appropriate checks and balances in place? What if portions of the coercive apparatus of the state can be captured by closed, unaccountable social groups, perhaps by means of corruptive or collusive behaviours? The actuality of Hobbes's concerns lingers.

A 'radicalisation' of empiricism occurred in George Berkeley and David Hume. Berkeley (see Opera Omnia) claimed that 'matter does not exist and that material objects are only ideas that God shares with us, from time to time. His slogan esse est percipi - to be is to be perceived - was widely quoted and widely mocked' (Kenny, 2010, p. 560). Berkeley's bequest ${ }^{19}$ will be picked up by idealist philosophy within a different frame.

Hume's poignant critiques of the possibility of knowledge - notably of the limits of empirical knowledge, which for the philosopher is the only possible form of knowledge - still occupy centre stage in contemporary culture (Hume, 1777). A contested claim made by Hume regards whether the notion of causality is ultimately significant, or rather what humans can see when they think to be observing causality in action (that ' $\mathrm{A}$ is the cause of the effect B') is only a regular conjunction of events, a temporal order whereby we first observe A and then after a temporal lag we observe B. His philosophical inheritance furnishes continued stimuli to constantly be vigilant and aware of the uncertain bases of human knowledge and to draw the borders of the knowable and the validity of what is known; Hume's formulation of the notion of 'belief' has also been widely picked up in sociology, whereby the observation that beliefs lead human beings to undertake certain courses of action rather than others is a useful starting point for innumerable streams of sociological research; equally influential has been Hume's notion of moral sentiments and the idea that sympathy for other human beings may represent the root of natural virtues such as meekness, clemency or generosity (Kenny, 2010, p. 697).

However, there seems to be an irrational drift of empiricism with Hume: in his thought, empiricism might have pushed itself beyond healthy critical vigilance and awareness of the limits of human knowledge, over the cliff of irrationality (Reale and Antiseri, 1988, pp. 430-1).

Empiricism continued to dominate British philosophical thought, and, amongst others, John Stuart Mill's A System of Logic (1843/2011) continued the great tradition of the British empiricism.

Implications for PA/Relevance for Philosophy for PA: as aptly indicated by Riccucci (2010), the dichotomy between a key tenet of rationalism (that ideas are at least partly innate) and of empiricism (that ideas can only be formed though sensorial perceptions, though they cannot be reduced to perceptions) remains a key point of contention in the PA debate. This topic is elaborated in Chapter 6, where possible ways for a fruitful integration of both perspectives for the advancement of PA studies are discussed. 


\section{ENLIGHTENMENT AND THE AGE OF THE REVOLUTIONS}

Enlightenment is a cultural-philosophical movement that came to define an epoch spanning the 18th century, which had its epicentre in France and spread throughout Europe. It is marked by the praise of the critical reason and an ambition to bring humankind into adulthood by the use of reason. The roots of many social sciences, like economics, can be traced back to this epoch. Also key notions like that of universal human rights (as codified for example in the UN charter of human rights) were fully theorised in this epoch, which is also the epoch of eventful moments for political thought like the American and the French revolutions. Indeed, this epoch brought about four major revolutions that have forever changed the course of history: the revolution in England, the English and notably the Glorious Revolution towards the end of the 17 th century, which put to the fore the political philosophy of liberalism and the notion of human rights, and the idea of representative (parliamentary) democracy; the French revolution, which redefined the notion of sovereignty (belonging to the people of a country) and established the compelling idea of the universal rights (the rights of the human being as such, of each and every human being, as well as the rights of the citizens of a country, in the famous French expression: les droits de l'homme et du citoyen), as well as introducing forms of direct democracy; the American revolution, establishing the right of each people to self-determination and propounding the ideal of democracy; and the industrial revolution, which has pushed through a quantum leap in the possibilities of manufacturing goods by resorting to non-animal power force - revolutions which have redefined the West (and the world), and which continue to define the West and its quest for the affirmation of universal human rights and liberal democracy as the principles underpinning public governance.

Turning to Enlightenment as a philosophical movement, this philosophical stream has emphasised the centrality of critical reasoning and stressed the power of reason to free humankind from its prejudices, and to lead it into continuous progress, both intellectual and material. A number of social sciences that are central to PA, like economics, became independent disciplines in this century (notably, economics detached from moral philosophy to become the discipline which studies the problem of making decisions on scarce resources to achieve objectives which are alternative and can, at least to some extent, be prioritised and ranked in terms of preference). It is not an overstatement to claim that the ideals of the Enlightenment represent a continued source of inspiration for many contemporary scholars, in all disciplines and this includes PA. The very idea of the encyclopaedia as an orderly collection of all human knowledge without establishing any special hierarchy amongst 
the branches of knowledge (encyclopaedias are in alphabetical order) is an invention of the Enlightenment, and continues to be an inspiration, including for PA (the second decade of the 21st century has witnessed a flourishing of encyclopaedias dedicated to PA, like for example the Oxford Encyclopaedia of Public Administration or the Springer General Encyclopaedia of Public Administration, Public Policy and Governance).

One author we pluck from this epoch for the significance of his thought on the philosophy of public administration is Christian Wolff (1679-1754). The definitions and distinctions he proposed wielded a large influence particularly on German philosophical thought over the century, notably his distinction between those disciplines that proceed by way of reason - for which the principle of non-contradiction is the ultimate criterion of truth - and those that proceed by way of empirical evidence. Importantly he was one of the first to develop a justification for state intervention in society beyond the strict regulatory function of protecting fundamental rights and administering justice. His thought is deemed by some PA scholars to be foundational to the modern theory of PA conceived of as a branch of knowledge: a concept encompassed in the German notion of staatswissenschaften, which might be translated as 'political science', but is a wider, more encompassing notion to indicate the range of disciplines that, combined, enable the knowledge of government in action (Drechsler, 2001b).

One dominant note, and possibly one key limitation, of the Enlightenment is an emphasis on a temporal knowledge. A dominant narrative of the Enlightenment is about the critical reason rising above prejudices that had accumulated in history and performing a liberating role from prejudices: the past is seen not so much as constitutive of the present, but rather as a source of errors that critical reason can amend. This assumption of human reason, now rid of prejudices operating at a sort of 'year zero', has informed important strands of social sciences. Indeed, the very idea of analysing a phenomenon starting from the assumption that $\mathrm{t}=0$ (time equals zero) is drawn from the consolidating method in the natural sciences after the scientific revolution and has gained traction in the social sciences as well. As we examine in the next chapter, philosophers like Hegel reacted harshly to this assumption and Hegel's dialectical approach where the whole of the past is conserved in the present through the synthesis of thesis and antithesis presents an abysmally different philosophical stance.

In conclusion, although it is up to historians to gauge the extent to which the Enlightenment still inspires contemporary scholarly work across the disciplines, and notably for our purposes in the disciplines related to PA, it appears a warranted claim that much of the thrust of the Enlightenment in terms of scholarly inquiry being aimed at dismantling prejudices, unveiling biased opinions and, by resorting to critical reasoning, shedding light on phenomena 
is something that still enthuses scholars and the self-conception that social scientists have of their mission. Equally, the idea that critical reason can amend past errors and make mankind start from 'year zero' still finds adherents in different milieus, both of scholars and practitioners.

The dawn of what we nowadays call 'the modern age' also gave rise to another distinctive feature: the conception of innovation (in any dimension: not just technological or industrial, but more broadly social and political) as a permanent thrust of a society has become a defining trait of European civilisation first, and the entire world later on.

Implications for PA/Relevance for Philosophy for PA: the Enlightenment provided the intellectual environment for the establishment and development of the social sciences (e.g. economics) in the terms in which they are conceived of nowadays. Also the conception of the 'encyclopaedia' and the idea of taking stock of existing knowledge without putting it in a hierarchy but rather, more humbly, listing what is known in alphabetical order originated in this epoch. The mushrooming 'encyclopaedias of PA' of these days are the direct heirs of this idea matured in 18th-century France. France - alongside England and the US - also gave birth to the notion of universal rights and the universal rights discourse that is so centre stage in nowadays politics, and thence it ought to be also in the PA debate. Implications of the rights of every human being as such and the rights of the citizen in her/his capacity as citizen of a country (in the famous French expression: les droits de l'homme et du citoyen) are also crucial to making sense of the development of social rights, the welfare state, and to contemporary notions of welfare governance and welfare society.

\section{NOTES}

1. It is interesting to note that the Greek alphabet, which originated from the Phoenician signary (Phoenician is a West Semitic language like Hebrew. In fact, 'aleph' and 'bet' - in their Hebrew form - are the first two characters of the Semitic system, from which the Greek term 'alphabet' originates), is in itself an ingenuous invention of the Greek, in a sense preparatory to philosophical speculation. As explained by Sansone (2009, pp. 37-9), while in the Phoenician signary the fourth symbol (dalet, represented by the symbol $\Delta$ ) may represent any one of the syllables $d a, d e, d i, d o$ or $d u$, the fourth character of the Greek alphabet (delta or $\Delta$ ) represents that which the syllables da, de, di, do, and du have in common (the sound ' $d$ '). The Greek letter delta 'stands for something that cannot be pronounced independently and can be defined in abstract terms: the Greek alphabet is analytical, in a way that Phoenician is not, in the sense that it reduces the sounds of the spoken language to its elements, beyond which it cannot further be reduced. In fact, "elements" (stoicheia) is the word used to refer to the letters of the alphabet, the same word they used to refer to the material elements of the physical world' (Sansone, 2009, p. 39). The Greek language - even the alphabet - was conducive to abstract, speculative reasoning. The German philosopher Heidegger even claimed that 'Being' revealed itself in different epochs in one preferred language: 
first Greek, then Latin, then German. This statement was indicted as 'ontological racism', that is, that one specific 'national' language conveys and leads to Being itself in ways that other languages cannot, and we concur with the accusation. However, the power of the Greek language and alphabetic system undoubtedly facilitated the giant leap in philosophical speculation that occurred during the Classical period of the Greek civilisation.

2. The English language may be misleading here, because of the presence in 'being' of the suffix 'ing', which denotes movement and change. This is not the case in the Greek öv, on, or the Latin, esse. Linguistic considerations also raise challenging speculative questions about the structure of the Greek language, which is a predicative language, differently from other languages (like for example Chinese), which are not: would the very formulation of Parmenides's propositions have been different in a non-predicative language? And would it have conveyed the same meanings? This question also relates to the role the Greek language, its structure and configuration, may have had in triggering the ontological quest that has been part and parcel of the Greek civilisation.

3. A footnote on Aristotle's bequest might be worthy of attention, especially for readers schooled in countries which place a great emphasis on teaching the achievements of the modern natural sciences, but less emphasis on educating pupils, at secondary school, also on philosophy and metaphysics (such may be the case, e.g. for a number of Anglophone countries): it is in these contexts very often pointed out at school two things which Aristotle did get wrong: the principle of inertia in physics, and the geo-centrism in astronomy. This may leave the student, at least in the back of her/his mind, with some sense of fallacy associated with Aristotle's thinking across the board. It should be pointed out that Aristotle is a giant of metaphysics, who was limited by the available observations at the time as regards the advancement of physics, but crucially the questions he addressed are metaphysical in nature, and it is on these terms - that of metaphysical thinking - that Aristotle's contribution to human knowledge should be gauged.

4. Aristotle is also credited with having first introduced the distinction between specific disciplines or sciences (in Greek, episteme), characterised by a specified subject matter and method, and philosophy as such.

5. Aristotle already posited that the actuality of intellect and the actuality of intellect's object is one and the same. Renaissance's thought, heavily inspired by a neo-Platonism mediated and actually mostly derived from Plotinus's thought, conceived of a form of immortality for the contemplating person. Those living a life attaining the contemplation of fundamental truths enjoy a form of immortality: when contemplating, the contemplating intellect and the contemplated object are one and the same. The person contemplating an 'eternal truth' partakes of that very truth and of its eternal character and therefore enjoys a form of immortality by partaking of the eternality of the truth it contemplates.

6. This is also referred to as 'positive theology'. Negative theology develops a form of knowledge of the divine by discerning what properties of worldly things are not participated by God.

7. Aquinas proposes a number of proofs - five to be precise - of the existence of God, which cannot be illustrated here. But the reader will have at this point surmised one and probably the favourite one takes the move from the contingency of all entities: only pure actuality - God is being - can enable potentiality to become actual - entities have being. If all is just potential, and at some point in time should have not existed, there has to have been a moment in time when nothing existed. 
But how can something come out of nothing? A cause that is not contingent must be posited: and this is God.

8. Establishment of universities and the foundation of the religious orders of mendicant friars were two events of eminent importance to the development of philosophy (alongside the full translation and circulation of Aristotle's body of works), as witnessed by the belonging of the main protagonists of the dispute over the universals: William Ockham and John Duns Scotus were Franciscan friars ('Friar Minors', 'Grey Friars') like St Bonaventure; Thomas Aquinas was a Dominican friar (the so-called 'Black Friars' because of the name of their habit, or 'Friar Preachers'). They taught in the newly established universities of Oxford and Paris.

9. For Scotus, it is not matter to be the principle of individuation (like in Aristotle): it is neither matter nor form nor the composite to individuate a thing, but a third thing, its haecceitas or 'thisness' (being 'this'), to make individuation. To illustrate with an example, in Socrates we have both a common human nature (essence or form) and an individualising principle ('this' specific human being is Socrates, not anybody else). This principle of individuation is an attempt to address the major problem of what makes something univocal and distinguishable even if it belongs to a species or categories (there is a strong echo here of the dispute over the universals which continued to rage at the time Scotus was writing), as well as an attempt to revisit the issue of the One and the Many. It has raised severe criticisms. Two major problems can be identified. One definitional regarding the haecceitas: what is it? Is this notion useful in order to better our understanding or not? Ockham would answer negatively and would suggest to eliminate it as a non-useful concept: it falls under the axe of Ockham's razor, a notion that is introduced in the following paragraph. The second problem concerns the implications of foregoing matter as the principle of individuation: if it is neither form nor matter to be the principle of individuation, what is left?

10. A distinction should be made between the conceptualisation of a whole alternative world (with properties different from those of this world) and a different state of affairs to what actually happened (as in counterfactual arguments), where the properties of this world are assumed to continue to be in place.

11. The main thrust of Ockham's philosophy is limiting the scope of what can be explained by reason in order to give way to faith (although interestingly in his proof of God's existence he emphasises the 'remaining into being' of entities, rather than the act with which they are initially created and enter into being as the proof of God's existence: a line of reasoning that seems to tie closely with Aquinas's philosophy whereby things receive their being by Being-God).

12. Including mental experiments, like those carried out by Galileo - a method which subsequently came to be neglected, at least until an entire theory that revolutionised physics, the theory of relativity worked out by Albert Einstein and initially entirely based on mental experiments - reinstated in the community of scientists a heedful attitude towards the significance of mental experiments.

13. The sociologist Karl Mannheim, also drawing from Marxian thought, as well as a range of prominent sociologist like Talcott Parsons, Robert Merton, Werner Stark and many others developed the branch of the sociology of knowledge in the 20th century.

14. According to Heisenberg's principle of indeterminacy and Schrödinger's famous equation, it is impossible to estimate with absolute precision the position and movement of a particle: the better the position is known, the more imprecise the movement of the particle can be estimated, and vice versa. What we are left with 
is a distribution of probability of presence of the particle (a 'cloud' where the particle is), although we may be somewhat reassured by the fact that Schrodinger's equation states that the integral of the position of the particle equals 1 , that is, that the particle is somewhere in the universe!

15. Recent astronomical theories postulate the existence of an invisible dark matter that can be detected only due to the gravitational field it causes, that is, it apparently is a causal agent because it generated a gravitational field, but it is impossible to locate in space, and hence its extension cannot be measured - if it exists at all.

16. It goes without saying many philosophers radically objected to both these propositions: that animals are machines and that the human being is a mix of two difference substances. We will see the radical critique formulated by Bergson in this regard by advancing an alternative metaphysics of life and the universe.

17. The British medieval philosophers (whom we have already encountered) who had already ploughed the terrain of Anglophone empiricism. However, an important part of their works was written in the then lingua franca - the vehicle language of the medieval time - which was Latin rather than English.

18. The Latin etymology of the word substance is 'what lies underneath', and in this sense can also be interpreted as 'what sustains'.

19. A popularisation of this idea is purveyed by the movie Matrix, where human beings are portrayed to live an altogether mental life. 